\title{
Cosmogenic nuclide and solute flux data from central Cuba emphasize the importance of both physical and chemical denudation in highly weathered landscapes
}

Mae Kate Campbell ${ }^{1,2}$, Paul R. Bierman ${ }^{2,3}$, Amanda Schmidtt, Rita Sibello Hernández ${ }^{5}$, Alejandro

5 García-Moya ${ }^{5}$, Lee B. Corbett ${ }^{1}$, Alan Hidy $^{6}$, Héctor Cartas Águila ${ }^{5}$, Aniel Guillén Arruebarrena ${ }^{5}$, Greg Balco $^{7}$, David Dethier ${ }^{8}$, Marc Caffee ${ }^{9}$

${ }^{1}$ Department of Geology, University of Vermont, Burlington, VT 05405, USA

${ }^{2}$ Gund Institute for Environment, University of Vermont, Burlington, VT 05405

${ }^{3}$ Rubenstein School of the Environment and Natural Resources, the University of Vermont, Burlington, VT 05405, USA

${ }^{4}$ Department of Geology, Oberlin College, Oberlin, OH 44074, USA

${ }^{5}$ Centro de Estudios Ambientales de Cienfuegos, Departamento de Estudio de la Contaminación Ambiental. AP 5, 59350, Ciudad Nuclear, Cienfuegos, Cuba

${ }^{6}$ Atmospheric, Earth, and Energy Division, Lawrence Livermore National Laboratory, Livermore, CA 94550, USA

${ }^{7}$ Berkeley Geochronology Center, Berkeley, CA 94709, USA

$15{ }^{8}$ Department of Geosciences, Williams College, Williamstown, MA 01267, USA

${ }^{9}$ Department of Physics and Astronomy and Department of Earth, Atmospheric, and Planetary Sciences, Purdue University, West Lafayette, IN 47907, USA

Correspondence to: Amanda H. Schmidt (aschmidt@oberlin.edu)

Abstract. We consider measurements of both in situ produced cosmogenic nuclides and dissolved load flux to characterize

20 the processes and pace of landscape change in central Cuba. The tropical landscape of Cuba is losing mass in multiple ways, making it difficult to quantify total denudation rates and thus to assess the impact of agricultural practices on rates of contemporary landscape change. Long-term sediment generation rates inferred from ${ }^{26} \mathrm{Al}$ and ${ }^{10} \mathrm{Be}$ concentrations in quartz extracted from central Cuban river sand range from 3.7-182 tons $\mathrm{km}^{-2} \mathrm{yr}^{-1}$ (mean $=62$, median $=57$ ). Rock dissolution rates $\left(24-154\right.$ tons $\mathrm{km}^{-2} \mathrm{yr}^{-1}$; mean $=84$, median $\left.=78\right)$ inferred from stream solute loads exceed measured cosmogenic nuclide-

25 derived sediment generation rates in 15 of 22 basins, indicating significant landscape-scale mass loss not reflected in the cosmogenic nuclide measurements. ${ }^{26} \mathrm{Al} /{ }^{10} \mathrm{Be}$ ratios lower than that of surface production are consistent with the presence of a deep, mixed, regolith layer in the five basins that have the greatest disagreement between rock dissolution rates (high) and sediment generation rates inferred from cosmogenic nuclide concentrations (low). Our data show that accounting for the contribution of mineral dissolution at depth in calculations of total denudation is particularly important in the humid tropics, where dissolved load fluxes are high, and where mineral dissolution can occur many meters below the surface, beyond the 
https://doi.org/10.5194/gchron-2021-31

Preprint. Discussion started: 2 November 2021

(c) Author(s) 2021. CC BY 4.0 License.

(c) (i)
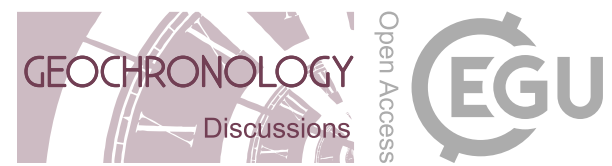

penetration depth of most cosmic rays and thus the production of most cosmogenic nuclides. Relying on cosmogenic nuclide data or stream solute fluxes alone would both lead to underestimates of total landscape denudation in the central Cuba, emphasizing the importance of combining these approaches to fully capture mass loss in tropical landscapes.

\section{Introduction}

This study presents measurements of cosmogenic nuclides in river sand and solute fluxes in central Cuba that highlight the importance of both physical and chemical weathering in humid, tropical landscapes. Cosmogenic nuclide concentrations of river sand have been used to quantify sediment generation rates and bedrock-equivalent lowering rates since the 1990s (Brown et al., 1995; Granger et al., 1996; Bierman and Steig, 1996; Portenga and Bierman, 2011; Codilean et al., 2018). Cosmogenic nuclides are commonly used to infer combined rates of physical erosion and rock dissolution

40 (Regard et al., 2016), also referred to as chemical weathering, under the assumption that both occur primarily within the uppermost meter or two of Earth's surface, the penetration depth of the cosmic ray neutrons responsible for producing most cosmogenic nuclides via spallation reactions (Bierman and Steig, 1996).

Such rates are often assumed to represent total landscape denudation, but failure to account for rock dissolution at depth and the export of mass as dissolved load below the spallation-dominated production zone (below $\sim 2 \mathrm{~m}$ ) can result in a low bias for cosmogenic nuclide-derived erosion rate estimates (Small et al., 1999; Riebe et al., 2001a; Dixon et al., 2009a). Measuring both physical erosion and rock dissolution is essential for understanding landscape evolution, soil production, and climate regulation (Riebe et al., 2003). Accurately establishing long-term denudation rates provides important context for understanding the effects of human activity on erosion (Reusser et al., 2015; Nearing et al., 2017), and for other common applications of cosmogenic nuclides at the basin-scale, such as quantifying the effect of tectonics (Scherler et al., 2014),

50 climate (Marshall et al., 2017), and baselevel change (Reinhardt et al., 2007) on rates of landscape change over time.

Accounting for rock dissolution is particularly important for interpreting rates of landscape change in areas with the potential for significant groundwater-rock interactions at depth. This includes any landscape where the physical removal of mass is slow, allowing for prolonged water-rock interactions, such as low-relief landscapes (Ollier, 1988). Landscape features that facilitate water-rock interaction, such as thick saprolite (Dixon et al., 2009a), extensively jointed/fractured

55 bedrock (Ollier, 1988), or readily soluble rocks, such as karst systems (Pope, 2013) and evaporite deposits can also contribute to significant rock dissolution at depth. Such landscapes can develop in any climate; however, conditions in the humid tropics are often favorable for prolonged and extensive water rock-interaction. The absence of recent glaciation 
https://doi.org/10.5194/gchron-2021-31

Preprint. Discussion started: 2 November 2021

(c) Author(s) 2021. CC BY 4.0 License.

(c) (i)

(Modenesi-Gauttieri et al., 2011), presence of active groundwater flow systems year-round (Ollier, 1988), and large amounts of precipitation create ideal conditions for rock dissolution at depth.

Rock dissolution rates in the tropics are among the highest globally (Pope, 2013); yet, global compilations of cosmogenic nuclide data from river sand suggest sediment generation rates in the tropics are slower than most other climate zones (Portenga and Bierman, 2011), consistent with the potential for cosmogenic nuclide-derived rates of landscape change to significantly underestimate total landscape denudation in areas where deep rock dissolution is ubiquitous. As the use of cosmogenic nuclides to measure erosion rates in the tropics expands (e.g. Cherem et al., 2012; Barreto et al., 2013; Derrieux

65 et al., 2014; Mandal et al., 2015; Sosa Gonzalez et al., 2016a; Jonell et al., 2017), considering the potential influence of rock dissolution at depth and thus not captured in cosmogenic nuclide-derived erosion rates will lead to more accurate estimates of total denudation. Basin-wide rock dissolution rates can be quantified by measuring river water chemistry and flow over time (Dunne, 1978); however, only a few studies focused in the tropics compare cosmogenic nuclide-derived rates of sediment generation to measurements of dissolved load flux in streams (e.g. Salgado et al., 2006; Hinderer et al., 2013; Regard et al., 2016).

Here, we explore the relationships between surface denudation and rock dissolution at depth in a tropical landscape where mass is being lost by multiple processes. We measured in situ ${ }^{26} \mathrm{Al}$ and ${ }^{10} \mathrm{Be}$ in riverine quartz, and stream water dissolved loads, in humid, tropical central Cuba to characterize the rates and processes by which the Cuban landscape is changing, and to place these data in a global context. Throughout this paper, we refer to rates of landscape mass loss

calculated from ${ }^{26} \mathrm{Al}$ and ${ }^{10} \mathrm{Be}$ as sediment generation rates, and rates of landscape mass loss inferred from measurements of stream water dissolved loads as rates of rock dissolution — all in units of mass per unit area over time. Our findings illustrate the importance of considering rock dissolution when using cosmogenic nuclides to assess rates of landscape change in areas with the potential for significant mass loss by solution at depth, and provide a geologic baseline for assessing the impact of human actions on the Cuban landscape.

\section{Background}

\subsection{Quantifying basin denudation with cosmogenic nuclides: approaches and limitations}

Landscape-scale denudation occurs through both physical removal of mass (erosion) and chemical dissolution of minerals in rocks. Sediment produced by eroding bedrock travels downslope towards base level, whereas rock dissolution moves mass in solution from the landscape to rivers, then to the ocean. Measurement of cosmogenic nuclides in river 
https://doi.org/10.5194/gchron-2021-31

Preprint. Discussion started: 2 November 2021

(c) Author(s) 2021. CC BY 4.0 License.

(c) (i)

85 sediment can be used to infer the spatially averaged sediment generation rate of a drainage basin (Brown et al., 1995; Granger et al., 1996; Bierman and Steig, 1996), but does not provide insight about processes—-such as rock dissolutionoccurring at depth. Assuming a density of the source rock, one can calculate equivalent rates of landscape lowering over time. In a basin that is steadily eroding, the concentration of cosmogenic nuclides in a sediment sample reflects the rate at which overlying mass at and near the surface was removed as the material was exhumed, through both physical erosion and rock dissolution (Lal, 1991).

Measuring multiple cosmogenic nuclides with different half lives in the same sample can provide more information on the exposure history of surface materials, such as soil mixing and residence time (Lal and Chen, 2005), as well as sediment storage within the watershed (Granger and Muzikar, 2001). The production ratio of ${ }^{26} \mathrm{Al} /{ }^{10} \mathrm{Be}$ at the surface at midand low-latitudes is $\sim 6.75$ (Nishiizumi et al., 1989; Balco et al., 2008). If sediment that has accumulated cosmogenic nuclides is buried such that production is negligible, this ratio decreases because ${ }^{26} \mathrm{Al}$ decays more rapidly than ${ }^{10} \mathrm{Be}$. Similarly, vertical mixing within a soil column has the effect of increasing the near-surface residence time of sediment grains, suppressing the ${ }^{26} \mathrm{Al} /{ }^{10} \mathrm{Be}$ ratio in sediment shed from the landscape surface during erosion (Makhubela et al., 2019). Isotope concentrations are commonly examined using a 2-isotope diagram, in which the $\mathrm{y}$-axis is the ${ }^{26} \mathrm{Al} /{ }^{10} \mathrm{Be}$ ratio and the $\mathrm{x}$-axis is the concentration of ${ }^{10} \mathrm{Be}$ (Klein et al., 1986; Granger, 2006). Sediment samples that have experienced constant exposure with no erosion, or constant exposure under steady-state erosion conditions, will plot within the simple exposure region along the top of the diagram; samples that have experienced more complex exposure histories, including burial during or after cosmic-ray exposure, will plot below this region. Such complex histories could include development of a vertically mixed surface layer (Bierman, 1999; Lal and Chen, 2005).

Using measurements of cosmogenic nuclides to determine basin-averaged long-term total denudation rates requires

105 the assumptions that erosion of the basin is in steady-state, that the mineral used for cosmogenic nuclide measurements is uniformly distributed throughout the watershed, and that denudation occurs within the penetration depth of most cosmic rays, the upper several meters of Earth's surface (Bierman and Steig, 1996). The grain size fraction selected for cosmogenic nuclide analysis must also be representative of the grain size distribution of sediment being produced on slopes (Lukens et al., 2016).

Denudation rates calculated from cosmogenic nuclides may not represent total landscape denudation rates if these methodological assumptions are violated. Rock dissolution can leave sediment enriched in resistant mineral phases, such as zircon, titanite, and quartz - the mineral in which ${ }^{26} \mathrm{Al}$ and ${ }^{10} \mathrm{Be}$ are most commonly measured (Riebe and Granger, 2013). 
https://doi.org/10.5194/gchron-2021-31

Preprint. Discussion started: 2 November 2021

(c) Author(s) 2021. CC BY 4.0 License.

(c) (i)
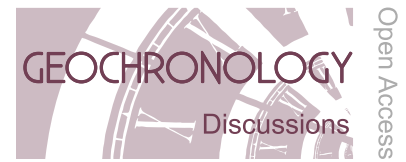

EGU

Such enrichment produces underestimates of long-term denudation rates unless accounted for, because the enriched mineral will have a longer residence time relative to the surrounding regolith (Riebe et al., 2001a; Ferrier and Kirchner, 2008).

115 Calculations of denudation rates from cosmogenic nuclide concentrations also rely on the assumption that mass loss is occurring primarily through surface lowering; however, some rock dissolution and, thus, some transfer of mass from rock to groundwater solutions occurs below the depth of most cosmogenic nuclide production (Fig. 1; Small et al., 1999; Dixon et al., 2009a; Riebe and Granger, 2013). In areas with significant rock dissolution at depth, denudation rates inferred from cosmogenic nuclides underestimate total denudation because some mass loss occurs below the depth of most nuclide production.

\subsection{Subsection (as Heading 2)}

Although the importance of accounting for chemical weathering when calculating cosmogenic denudation rates has been recognized (Small et al., 1999; Riebe et al., 2001a; Dixon et al., 2009a; Riebe and Granger, 2013), few studies incorporate rock dissolution information or apply correction factors to cosmogenic nuclide-derived rates. In the tropics, some studies have compared export rates from dissolved loads in streams to catchment-averaged sediment generation rates from cosmogenic nuclide measurements, but have considered these two metrics of landscape change separately (Von Blackenburg et al., 2004; Salgado et al., 2006; Hinderer et al., 2013). More broadly, other studies use the measurement of insoluble elements in bedrock, saprolite, and soil to quantify quartz enrichment through the weathering process and calculate correction factors that account for the influence of rock dissolution at and near the surface (Small et al., 1999; Riebe et al.,

130 2001a), at depth (Dixon et al., 2009b), or both (Riebe and Granger, 2013).

Of studies that do correct for the influence of chemical weathering when calculating cosmogenic nuclide-derived denudation rates, Riebe and Granger (2013)'s chemical erosion factor (CEF) method, or earlier quartz enrichment factor method (Riebe et al., 2001a), are often used (Regard et al., 2016). Calculating a CEF requires measurements of soil thickness and density, and determining the concentration of the mineral used in cosmogenic nuclide measurements (commonly quartz)

135 and an insoluble element (commonly Zr) in numerous samples of soil, saprolite, and unweathered bedrock; the method is underpinned by the assumption that chemical erosion is occurring exclusively in well-mixed soils and deep saprolite (Riebe and Granger, 2013). Denudation rates calculated from cosmogenic nuclide measurements can be multiplied by the CEF to correct for the effects of deep and near surface chemical erosion (Riebe and Granger, 2013). Chemical erosion factors reported in tropical environments include a CEF of 1.79 in Puerto Rico (Riebe and Granger, 2013) and 3.2 in Cameroon 
https://doi.org/10.5194/gchron-2021-31

Preprint. Discussion started: 2 November 2021

(c) Author(s) 2021. CC BY 4.0 License.

(c) (i)

140 (Regard et al., 2016), demonstrating how significantly cosmogenic nuclide-derived estimates of denudation can underestimate total denudation rates by not accounting for the effects of rock dissolution.

\section{Study area}

Cuba is the largest Caribbean island $\left(\sim 110,000 \mathrm{~km}^{2}\right)$ and is situated along the boundary between the Caribbean and North American plates. Reflecting this complex tectonic setting, Cuban geology is varied (Pardo, 2009). Basement

145 lithologies include marine deposits, accreted volcanic terrains, passive-margin sediments, and obducted ophiolite, all unconformably overlain by slightly-deformed autochthonous coarse clastics and limestone (Iturralde-Vinent et al., 2016). The Cuban landscape features a mountainous spine $(600-1970 \mathrm{~m})$ descending into low relief coastal plains, except along portions of the south coast where mountains meet the sea. This drainage divide parallels Cuba's east-west orientation, creating rivers that travel relatively short distances from headwaters to base level (Galford et al., 2018). Cuba's climate is tropical wet and dry, with a mean annual temperature of $24.5^{\circ} \mathrm{C}$ and average annual precipitation of $1335 \mathrm{~mm} / \mathrm{yr} ; \sim 80 \%$ of this precipitation is delivered during the wet season from May-October (Llacer, 2012).

The Cuban landscape has been heavily altered by agriculture for centuries (Whitbeck, 1922). Prior knowledge of mass loss at the basin scale is limited to measurements of suspended sediment discharge for short periods between 1964 and 1983 for 32 Cuban rivers (Pérez Zorrilla and Ya Karasik, 1989), and measurements of dissolved loads in five limestone basins with karst (Pulina and Fagundo, 1992). In central Cuba, underlying basin rock type is the primary control on surface water geochemistry (Betancourt et al., 2012), a finding supported by geochemical analyses of river waters from the same basins sampled in this study (Bierman et al., 2020). Dissolved load fluxes carried by Cuban rivers (Bierman et al., 2020), and rock dissolution rates inferred from these fluxes, are consistent with rates reported for other Caribbean islands [Dominica, Guadeloupe, and Martinique from Rad et al. (2013) and Puerto Rico from White and Blum (1995)], and high compared to global data compiled by Larsen et al. (2014).

\section{Methods}

\subsection{Field methods}

We collected detrital sediment $(n=26)$ from the beds of active river channels in central Cuba, representing a variety of basin sizes, average slopes, and lithologies (Fig. 2; Supplement T1-2). Channel morphologies varied, but most streams 
https://doi.org/10.5194/gchron-2021-31

Preprint. Discussion started: 2 November 2021

(c) Author(s) 2021. CC BY 4.0 License.

(c) (i)

165 were incised, and many had exposed bedrock (see Bierman et al. (2020) for photos/descriptions of select field sites). Three sample sites are near previously-gauged hydrologic stations with discharge and suspended sediment records spanning 9-15 years (Pérez Zorrilla and Ya Karasik, 1989). We extracted drainage basins and then calculated basin slopes and effective elevations (Portenga and Bierman, 2011) using the ASTER Global Digital Elevation Model (Lpdaac), determined underlying basin rock types from the USGS Caribbean layer (French and Schenk, 2004), and utilized precipitation data from the

170 WorldClim dataset (Hijmans et al., 2005) to estimate basin-specific mean annual precipitation (MAP).

\subsection{Lab methods}

We prepared samples for cosmogenic analysis and extracted beryllium and aluminum following the methodology of Corbett et al. (2016). We sieved bulk sediment samples in the lab and used the $250-850 \mu \mathrm{m}$ grain size fraction for all samples, except for CU-120, which also includes finer material $(63-250 \mu \mathrm{m})$ due to low quartz content. Sediment samples were chemically etched to purify quartz and remove meteoric ${ }^{10} \mathrm{Be}$ (Kohl and Nishiizumi, 1992). 24 samples (including all 3 gauging station samples) yielded sufficient quartz for analysis. We measured quartz yields for all samples by recording the mass of sediment before and after dilute acid etching. We extracted ${ }^{26} \mathrm{Al}$ and ${ }^{10} \mathrm{Be}$ at the National Science Foundation/ University of Vermont Community Cosmogenic Facility, using $\sim 5-40 \mathrm{~g}$ of quartz per sample (mean $=24 \mathrm{~g}$ ). We added $\sim 250$ $\mu \mathrm{g}$ of Be to each sample using two different in-house made carriers (Supplement T5); the first batch used a low-ratio carrier made from beryl, while subsequent batches used a dilution of low-ratio commercial SPEX carrier. We added Al to samples with insufficient total Al using a commercial SPEX ICP standard in order to reach a total Al mass of $\sim 1500 \mu \mathrm{g}$ (Supplement T6). Samples were processed in batches of 12, each of which included at least one blank, and two batches included one quality control standard each (Corbett et al., 2019).

${ }^{10} \mathrm{Be} /{ }^{9} \mathrm{Be}$ and ${ }^{27} \mathrm{Al} /{ }^{26} \mathrm{Al}$ measurements $(\mathrm{n}=26$, including 2 duplicates $)$, were made by Accelerator Mass

185 Spectrometer (AMS) at the Purdue Rare Isotope Measurement Laboratory (PRIME). ${ }^{10}$ Be ratios were normalized against standard 07KNSTD3110 with an assumed ratio of $2850 \times 10^{-15}$ (Nishiizumi et al., 2007) and ${ }^{27} \mathrm{Al} /{ }^{26} \mathrm{Al}$ measurements were normalized against standard KNSTD with an assumed ratio of $1818 \times 10^{-15}$ (Nishiizumi, 2004). Laboratory replicate measurements of ${ }^{26} \mathrm{Al}$ and ${ }^{10} \mathrm{Be}$ agree to within $<2 \%$ (Supplement $\mathrm{T} 7 ; \mathrm{n}=2$ ). We corrected Be measurements by carrier type, since samples were prepared using two different in-house made carriers; we use the average of two process blanks

$190\left(1.91 \pm 1.01 \times 10^{-15} ; 1 \mathrm{SD}\right)$ to correct 10 samples, and the average of 3 process blanks $\left(4.14 \pm 1.19 \times 10^{-15} ; 1 \mathrm{SD}\right)$ for the 
https://doi.org/10.5194/gchron-2021-31

Preprint. Discussion started: 2 November 2021

(c) Author(s) 2021. CC BY 4.0 License.

(c) (i)

remaining samples (Supplement T3). We corrected Al measurements using a single process blank (1.92 $\pm 1.36 \times 10^{-15}$; Supplement T4). We subtracted blank ratios from sample ratios and propagated uncertainties in quadrature.

\subsection{Analytical methods}

We calculated erosion rates using version 3 of the online erosion rate calculator originally described by Balco et al.

195 (2008) and subsequently updated [wrapper: 3.0, erates: 3.0, muons: 3.1, validate: validate_v2_input.m - 3.0 consts: 2020-0826] using the effective elevation (Portenga and Bierman, 2011) calculated for the basin upstream of the sample collection point, a sample thickness of $0 \mathrm{~cm}$, a density of $2.6 \mathrm{~g} \mathrm{~cm}^{-3}$, and assuming no topographic shielding across this low-relief landscape. We report erosion rates using the Lal-Stone (St) (Lal, 1991; Stone, 2000) production scaling scheme.

Finally, for four samples with the highest ${ }^{10} \mathrm{Be}$ concentrations, we also measured concentrations of cosmogenic ${ }^{21} \mathrm{Ne}$ in quartz as an attempt to further distinguish simple and complex exposure histories (Supplement T10). Neon isotope measurements were made at the Berkeley Geochronology Center on aliquots of the same purified quartz samples used for ${ }^{26} \mathrm{Al} /{ }^{10} \mathrm{Be}$ analysis. They were done by vacuum degassing and noble gas mass spectrometry using the method described in Balter-Kennedy et al. (2020) and Balco and Shuster (2009).

We compare measured sediment generation rates to rock dissolution rates (inferred from measurements of dissolved loads in stream water) for the same basins. Across the literature, there is little consensus on calculating chemical weathering rates, with the greatest difference reflecting which elements are included as part of the total dissolved solids (TDS) term ( $\operatorname{Rad}$ et al., 2013). In our study area, the calculation of rock dissolution rates is further complicated by the variety of underlying rock types present in sampled basins (Supplement T2), which contribute different major ions as they dissolve. Rock dissolution rates for the same basins sampled in this study (Bierman et al., 2020) were calculated using all major 210 cations, anions (including all bicarbonate), and silica measured in stream water as TDS, multiplied by basin-specific runoff coefficients from GLOH2O (Beck et al., 2015; Beck et al., 2017). This approach provides an upper limit for rock dissolution rates.

Because we are interested in constraining the influence of rock dissolution on total landscape denudation (bedrockequivalent lowering), we use the same stream solute flux data but follow West et al. (2005)'s method that includes only 215 bicarbonate thought to derive from the weathering of carbonates in our calculation of TDS. The West et al. (2005) method underestimates rock dissolution rates in basins with geochemical evidence of evaporite deposits, but otherwise provides an estimate of mass loss resulting from both the weathering of silicate and/or carbonate rocks. Rock dissolution rates presented 
https://doi.org/10.5194/gchron-2021-31

Preprint. Discussion started: 2 November 2021

(c) Author(s) 2021. CC BY 4.0 License.

(c) (i)
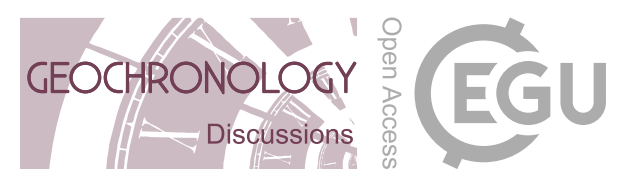

here are uncorrected for atmospheric inputs as site-specific atmospheric deposition information are not available; however, a survey of atmospheric inputs across Cuban cities (Préndez et al., 2014) suggests such deposition is a minor component of stream solute loads.

We explore the relationship between sediment generation rates and rock dissolution rates with landscape variables using linear correlations and their associated p-values. All reported means of sample populations are arithmetic means.

\section{Results}

Sediment generation rates (Supplement T8) calculated from measured concentrations of ${ }^{26} \mathrm{Al}$ and ${ }^{10} \mathrm{Be}$ (Supplement 225 T7) differed considerably between sites. ${ }^{10}$ Be-derived sediment generation rates (Fig. 3) range from 3.7-182 tons km-2 year ${ }^{-1}$ $($ mean $=59 \pm 53$, median $=41)$. Considered as bedrock lowering rates, these are 1.4-70 $\mathrm{m} / \mathrm{My}($ mean $=23 \pm 21$, median $=16)$ for ${ }^{10} \mathrm{Be}$ and $1.7-63 \mathrm{~m} / \mathrm{My}\left(\right.$ mean $=23 \pm 19$, median $=21$ ) for ${ }^{26} \mathrm{Al} .{ }^{26} \mathrm{Al} /{ }^{10} \mathrm{Be}$ ratios (Fig. 4) also varied considerably, ranging from 2.89-8.32 $($ mean $=5.7 \pm 1.2$, median $=6.9)$. Rock dissolution rates $($ Fig. 3$)$ range from 24-154 tons km ${ }^{-2}$ year ${ }^{-1}($ mean $=$ $84 \pm 34$, median $=78$ ) and are higher than cosmogenic nuclide-derived erosion rates in 16 of the 23 basins in which both measurements were made. The median rock dissolution rate is $1.4 \mathrm{X}$ higher than the median sediment generation rate.

Neon isotope measurements (Supplement T10) revealed unusually high total neon concentrations with isotope composition indistinguishable from atmosphere, so excess ${ }^{21} \mathrm{Ne}$ was likewise indistinguishable from zero. Expected cosmogenic ${ }^{21} \mathrm{Ne}$ concentrations in the samples we analyzed, calculated from observed ${ }^{10} \mathrm{Be}$ concentrations and the assumption of steady erosion (3-6 M atoms $\mathrm{g}^{-1}$ cosmogenic ${ }^{21} \mathrm{Ne}$ ), would comprise less than $2 \%$ of the total amount of ${ }^{21} \mathrm{Ne}$

235 we observed and would not be detectable at typical measurement uncertainties. Thus, the neon isotope measurements are not inconsistent with the ${ }^{26} \mathrm{Al}$ and ${ }^{10} \mathrm{Be}$ data, but do not provide any additional useful information.

There is lithological dependence of both sediment generation rates and rock dissolution rates at the basin scale (Fig. 5). Basins draining primarily sedimentary lithologies had the highest rock dissolution rates and the lowest sediment generation rates; this trend was reversed in basins draining primarily metamorphic lithologies. The sediment generation rates of sedimentary rocks were lower than the sediment generation rates of other rock types $(\mathrm{p}=0.02)$. Quartz yields $(0.5 \%-60 \%$, mean $=20 \%$, median $=27 \%$ ) were not correlated with any basin-scale variables (Supplement F1). Sediment generation rates in central Cuba are weakly and positively correlated with mean annual precipitation and slope (Fig. 6). Rock dissolution rates and sediment generation rates are not correlated (Fig. 7). The ${ }^{26} \mathrm{Al} /{ }^{10} \mathrm{Be}$ ratios of basins underlain by sedimentary rocks are distinctly lower than the ratios observed in basins underlain by metamorphic rocks $(\mathrm{p}=0.001)$. 
https://doi.org/10.5194/gchron-2021-31

Preprint. Discussion started: 2 November 2021

(c) Author(s) 2021. CC BY 4.0 License.

(c) (i)

Several basins (CU-106, 120, 121, 122, and 132) have much lower than average sediment generation rates (3.7-11 tons $\mathrm{km}^{-2}$ year ${ }^{-1}$ ), plot near each other outside of the simple exposure region on the right of the two-isotope diagram with low ${ }^{26} \mathrm{Al} /{ }^{10} \mathrm{Be}$ ratios (3.80-5.09), and have rock dissolution rates 9-32X higher than the sediment generation rates. The rock dissolution rates in two additional basins (CU-016 and 131) are 3.6-6X higher than their respective sediment generation rates; all also plot on the right side of the two-isotope diagram, and CU-016 falls far below the simple exposure region, with $\mathrm{a}^{26} \mathrm{Al} /{ }^{10} \mathrm{Be}$ ratio of 2.89 (Fig. 4).

\section{Discussion}

\subsection{Discordance between high rock dissolution rates and low sediment generation rates}

Rock dissolution rates exceed, sometimes by an order of magnitude, most corresponding sediment generation rates in Cuba, demonstrating that the cosmogenic nuclide measurements are an incomplete assessment of total mass loss from the landscape. This comparison shows that mass loss is occurring largely by solution in central Cuba, which is consistent with observations from other tropical landscapes (White et al., 1998; Von Blackenburg et al., 2004; Salgado et al., 2006; Regard et al., 2016). The predominance of rock dissolution in these landscapes is likely a reflection of the favorable weathering conditions created by tropical climates (Pope, 2013). In areas with slow physical erosion, chemical export is also favored (Anderson et al., 2007).

Underlying basin rock type and topography are important controlling factors in how and how rapidly the Cuban landscapes we studied are denuding. Correlations between rock dissolution and sediment generation rates with basin slope and elevation are influenced by the distribution of lithologies in our study area, as low-relief, soluble sedimentary rocks are concentrated at low elevations, and steeper, less soluble metamorphic rocks are concentrated at higher elevations. Whereas sediment generation rates are weakly and positively correlated with average basin slope $\left(\mathrm{p}=0.10, \mathrm{R}^{2}=0.13\right)$, rock dissolution rates are strongly negatively correlated $\left(\mathrm{p}=0.01, \mathrm{R}^{2}=0.27\right)$ with slope. Rock dissolution rates are also negatively correlated $\left(\mathrm{p}=0.01, \mathrm{R}^{2}=0.24\right)$ with average elevation. Rock type plays a key role in determining rock dissolution rates as well. Rock dissolution rates are highest in the low elevation, low slope basins underlain primarily by sedimentary rocks, and lowest in the steeper, high elevation metamorphic basins - the opposite trend observed in sediment generation rates. These trends emphasize the importance of low-relief topography and the availability of soluble rocks in driving the rate of rock dissolution in Cuba. 
https://doi.org/10.5194/gchron-2021-31

Preprint. Discussion started: 2 November 2021

(c) Author(s) 2021. CC BY 4.0 License.

(c) (i)

While most other studies that compare rock dissolution rates and sediment generation rates in the tropics documented rock dissolution rates within the range of cosmogenic nuclide-derived rates (Von Blackenburg et al., 2004; Salgado et al., 2006; Cherem et al., 2012; Sosa Gonzalez et al., 2016b), the mean rock dissolution rate in Cuba is 6X higher than corresponding cosmogenic nuclide-derived rates. Rock dissolution rates that significantly exceed corresponding ${ }^{10} \mathrm{Be}-$ inferred rates have been observed in Uganda (Hinderer et al., 2013) and Cameroon (Regard et al., 2016), where they were attributed to the influence of easily weathered volcanic tephras and deep weathering associated with thick regolith, respectively. As the discordance between high rock dissolution rates and low sediment generation rates observed in Cuba occurs in basins with different underlying lithologies, the disagreement between these rates suggests deep chemical weathering is occurring throughout central Cuba regardless of lithology.

The contrast between high rock dissolution rates and low sediment generation rates suggests that significant rock weathering is occurring below the depth of most cosmogenic nuclide production (Bierman and Steig, 1996; Fig. 1). Bierman et al. (2020) attribute high rock dissolution rates and the relationship between stream water chemistry and bedrock type in Cuba to extensive rock-groundwater interaction along subsurface flow paths, controlled by ongoing bedrock uplift and associated rock fracturing. The strong negative correlation between chemical denudation rates and average basin slope also supports the importance of deep weathering in landscape denudation, since such weathering occurs when rock dissolution progresses faster than weathering products are removed from the landscape, a process favored in low relief settings (Ollier, 1988). In contrast to other studies in the tropics that have observed generally positive correlations between sediment generation and rock dissolution rates (Salgado et al., 2006; Cherem et al., 2012; Sosa Gonzalez et al., 2016b), we do not observe a correlation between these metrics of landscape change in central Cuba (Fig. 7). The lack of correlation mandates that mass loss below the depth at which most cosmogenic nuclides are produced is an important component of denudation in Cuba. The prevalence of rock dissolution at depth in Cuba is consistent with findings from other humid, tropical landscapes, including Puerto Rico (White et al., 1998; Kurtz et al., 2011; Chapela Lara et al., 2017; Moore et al., 2019), Guadeloupe, Martinique, Réunion (Rad et al., 2007), and Hawaii (Schopka and Derry, 2012).

\section{$6.2 \mathrm{Low}{ }^{26} \mathrm{Al} /{ }^{10} \mathrm{Be}$ ratio evidence for a deep mixed surface layer and possible quartz enrichment}

${ }^{26} \mathrm{Al} /{ }^{10} \mathrm{Be}$ data in seven sampled basins are inconsistent with steady surface erosion (Fig. 4). The basin with the lowest ${ }^{26} \mathrm{Al} /{ }^{10} \mathrm{Be}$ ratio (CU-016; 2.89) is primarily underlain by what have been mapped as ultramafic rocks and has an average basin slope of $3^{\circ}$. All but one of other basins with ${ }^{26} \mathrm{Al} /{ }^{10} \mathrm{Be}$ ratios $\leq 5$ that plot significantly below the simple 
https://doi.org/10.5194/gchron-2021-31

Preprint. Discussion started: 2 November 2021

(c) Author(s) 2021. CC BY 4.0 License.

(c) (i)
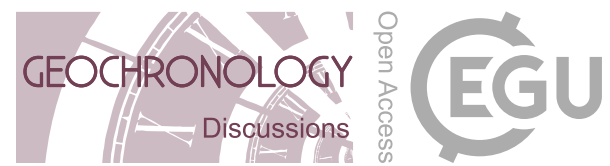

exposure region $(n=5)$ drain predominantly marine sedimentary lithologies, and have low average basin slopes $\left(0.5-0.7^{\circ}\right)$; the remaining sample drains primarily volcanic rocks and has an average basin slope of $0.6^{\circ}$.

These six basins underlain by marine or volcanic rocks have the highest ${ }^{10} \mathrm{Be}$ concentrations, indicating longer total exposure durations of the quartz we analyzed. The five basins underlain by marine rocks also demonstrate the greatest disagreement between high rock dissolution rates and low sediment generation rates (9-32X). Water geochemistry data from four of these basins (CU-120, 121 122, 132) suggest the presence of evaporites due to high concentrations of $\mathrm{Cl}, \mathrm{SO}_{4}, \mathrm{Br}$, and $\mathrm{Na}$ (Bierman et al., 2020), and the fifth basin (CU-106) is primarily underlain by the same marine unit as those the basins, presumptive evidence of the presence of evaporite deposits somewhere in the basin.

Observed ${ }^{26} \mathrm{Al} /{ }^{10} \mathrm{Be}$ ratios in six of the seven low-ratio samples (all except $\mathrm{CU}-016$ ) can be explained by prolonged near-surface exposure (Struck et al., 2018). We suspect that the inconsistency between measured ${ }^{26} \mathrm{Al} /{ }^{10} \mathrm{Be}$ ratios and those predicted by a simple steady surface erosion model is due to soil mixing. Typically, the lower boundary of the simple exposure region of a two-isotope diagram (Fig. 4) is constructed based on the assumption that all grains move monotonically towards the surface at the rate that the surface is eroding (Granger, 2006). Vertical mixing, due to bioturbation or other soil processes taking place in the upper layers of soil, violates this assumption. Within a mixed soil layer, grains circulate at a higher velocity than the erosion rate, and therefore experience both a different production rate than assumed by a simple steady surface erosion model and spend time buried. During burial, ${ }^{26} \mathrm{Al} /{ }^{10} \mathrm{Be}$ ratios lower and thus diverge from those predicted by a simple steady surface erosion model.

Rapid chemical denudation due to the presence of readily soluble evaporite and marine or volcanic deposits in these six basins likely enriches the remaining sediment in quartz. The combination of of mass loss by rock dissolution due to soluble deposits and the retention of weathering residuum favored by low topography allows less-soluble material (e.g., quartz) to accumulate at and near the surface, creating thick regolith. Extensive vertical mixing of near-surface soil, as is expected for flat, forested landscapes where the rate of bioturbation is likely very high in relation to slow erosion rates, leads to longer residence times for mineral grains, and therefore a lower ${ }^{26} \mathrm{Al} /{ }^{10} \mathrm{Be}$ ratio, in a surface mixed layer compared to a surface eroding at the same rate without vertical mixing.

This assertion is supported by the consistency between measured ${ }^{26} \mathrm{Al} /{ }^{10} \mathrm{Be}$ ratios and expected nuclide concentrations and ratios calculated assuming the presence of a mixed surface layer (per Lal and Chen (2005), equation 12). 
https://doi.org/10.5194/gchron-2021-31

Preprint. Discussion started: 2 November 2021

(c) Author(s) 2021. CC BY 4.0 License.

(c) (i)

Expected ${ }^{26} \mathrm{Al} /{ }^{10} \mathrm{Be}$ ratios calculated assuming a mixed layer depth of $40-160 \mathrm{~cm}$ agree well with measured low ${ }^{26} \mathrm{Al} /{ }^{10} \mathrm{Be}$ ratios from basins CU-122 and 132. This mixed layer depth range is consistent with the soil depths of $90-150 \mathrm{~cm}$ reported for the location of these basins (Bennett and Allison, 1928). In deeply weathered tropical soils, bioturbation can extend to depths of 3-4 m (Von Blackenburg et al., 2004) so it is plausible that mixing depths are even greater than the model suggests. Access restrictions in Cuba prevent us from directly measuring regolith depths.

The ${ }^{26} \mathrm{Al} /{ }^{10} \mathrm{Be}$ ratio in the lowest-ratio sample (CU-016) is too low to be attributed solely to the effects of a deep mixed surface layer, and requires that some fraction of the sample has experienced both surface exposure and a significant period of burial well below the surface where cosmogenic nuclide production is negligible. Factors that could lead to this low ratio include the incorporation of previously deeply buried sediment through channel avulsion (Wittmann et al., 2011) or incision into terraces (Hu et al., 2011). However, satellite image analysis does not provide compelling evidence, such as incised terraces, for the presence of previously exposed then deeply buried material.

Extensive subsurface dissolution leads to the observed and significant disagreement between slow sediment generation rates and fast rock dissolution rates. The lengthy exposure durations inferred from high ${ }^{10} \mathrm{Be}$ concentrations in quartz from CU-106, 120,121,122, 131, and 132 demonstrate that even in the high-precipitation, tropical environment of central Cuba, quartz can remain stable, with long residence times in the landscape of low-slope basins. However, this cannot be the entire story because of the low ${ }^{26} \mathrm{Al} /{ }^{10} \mathrm{Be}$ ratios we measure which mandate burial of sampled quartz during or after

340 exposure. We conclude that a combination of quartz enrichment due to high chemical weathering rates of soluble marine rocks in combination with very low slope basins and a deep mixing layer combine to generate detrital quartz with high concentrations of ${ }^{10} \mathrm{Be}$ and lower than expected ${ }^{26} \mathrm{Al} /{ }^{10} \mathrm{Be}$ ratios.

\subsection{Constraining total landscape denudation}

The disagreement between high rock dissolution rates and low sediment generation rates raises questions about how to best characterize total landscape denudation rates, since neither cosmogenic nuclide measurements nor stream solute flux are capturing all or even, in some cases, the majority of landscape denudation in central Cuba. Evidence for deep rock dissolution suggests that sediments and solutes are being sourced at least partially from different depths in the landscape. Since it is clear that the majority of mass loss in Cuba occurs in solution (rock dissolution rates are higher than sediment generation rates in most basins), rock dissolution rates represent a minimum bound on total landscape denudation. 
https://doi.org/10.5194/gchron-2021-31

Preprint. Discussion started: 2 November 2021

(c) Author(s) 2021. CC BY 4.0 License.

(c) (i)

Treating the removal of mass in solution and through physical erosion as entirely discrete processes happening at different depths in the landscape allows us to set a maximum bound on total landscape denudation: the sum of inferred rock dissolution rates and sediment generation rates. In basins with evidence of evaporite deposits, the total rate of landscape denudation would be even higher than the sum of sediment generation rates and rock dissolution rates presented in this study, as the method we used for calculating chemical denudation rates (West et al., 2005) does not include some ions that result from the dissolution of evaporites (such as $\mathrm{Br}$ or carbonate that does not result from the dissolution of carbonate rocks).

Summing sediment generation rates and chemical denudation rates increases estimates of total landscape denudation across study basins by a factor of 1.4-33 (mean $=6.4$, median $=2.5$ ) above sediment generation rates. Disregarding the extreme examples of the basins with evidence of evaporite deposits leads to an average increase of a factor of 2.8 (median $=2.2)$ above sediment generation rates. These mean and median values are between the reported CEF of 1.79 for the Luquillo Critical Zone Observatory in humid, tropical Puerto Rico (Riebe and Granger, 2013) and the CEF of 3.2 for the thickly saprolite-mantled, tropical environment of south Cameroon (Regard et al., 2016). These comparisons suggest that for landscapes with a significant proportion of total denudation occurring through deep rock dissolution, summing rock dissolution rates and cosmogenic nuclide-derived rates provides a reasonable estimate of total landscape denudation.

In landscapes like central Cuba, total denudation rates may be difficult to predict based on landscape metrics. Summed chemical denudation rates and cosmogenic nuclide-derived erosion rates are not correlated with rock type, as rock type appears to have opposing influences on these rates (i.e., basins underlain by sedimentary rocks had the highest rock dissolution rates but lowest cosmogenic nuclide-derived rates). Similarly, summed rock dissolution rates and cosmogenic nuclide-derived rates are not correlated with mean basin elevation or mean basin slope (Fig. 6), since ${ }^{10} \mathrm{Be}$-derived rates were highest in high elevation, steep basins and rock dissolution rates were highest in low slope, low elevation basinsrelationships that are primarily controlled by the influence of rock type on these two different denudational processes.

In central Cuba, the lack of correlation between summed rock dissolution rates and sediment generation rates suggests a possible mechanism for limiting total reductions in landscape relief. While global data demonstrates significant, positive correlations between sediment generation rates and basin slope and relief (Portenga and Bierman, 2011), accounting

375 for the influence of rock dissolution may alter this dynamic. The possibility of combined physical and chemical processes limiting reductions in relief has significant implications for the study of deeply weathered, high relief tropical landscapes. The dual importance of rock dissolution in low-lying areas and physical erosion in steeper terrain could explain the 
https://doi.org/10.5194/gchron-2021-31

Preprint. Discussion started: 2 November 2021

(c) Author(s) 2021. CC BY 4.0 License.

(c) (i)
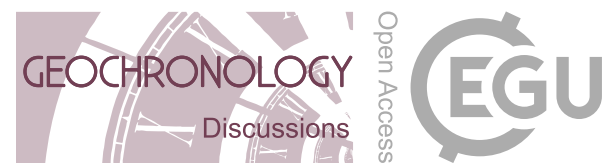

relationship behind sustained high relief topography and low sediment generation rates common across some tropical landscapes, such as Brazil (Vasconcelos et al., 2019) or Sri Lanka (Von Blackenburg et al., 2004). As lowlands are

weathering primarily through rock dissolution and high relief areas are weathering primarily through sediment generation, total relief would remain relatively unchanged.

Regardless of rock type, however, both cosmogenic nuclide-derived erosion rates and summed chemical denudation rates and cosmogenic nuclide-derived erosion rates are positively correlated with MAP $\left(p=0.005, R^{2}=0.34\right)$. While MAP does not vary widely across our study basins in central Cuba (956 to $1555 \mathrm{~mm}$ /year), this correlation suggests a climatic control on denudation rates across this landscape. This finding is contrary to other studies in the humid tropics (Von Blackenburg et al., 2004), and beyond (Riebe et al., 2001b; Portenga and Bierman, 2011), that have found no correlations between climate variables and cosmogenic nuclide-derived long-term erosion rates. Since in Cuba sediment generation rates are positively correlated with MAP but chemical denudation rates are uncorrelated with MAP, this trend likely highlights the importance of rainfall in allowing for the physical export of sediment from a drainage basin that is transport-limited rather than weathering-limited.

Our data clearly demonstrate that cosmogenic nuclide measurements can underestimate total denudation in landscapes with significant rock dissolution at depth, particularly in the tropics, suggesting that similar underestimates of total denudation rates using measurements of cosmogenic nuclides may be a factor in other tropical landscapes. While rock dissolution rates in the tropics have been documented as among the highest globally (White and Blum, 1995; Rad et al.,

395 2013; Larsen et al., 2014), a global compilation of sediment generation rates demonstrated that such rates in the tropics are lower than all other climate zones, apart from arid regions (Portenga and Bierman, 2011). The contrast between these two depictions of tropical denudation suggests that ${ }^{10} \mathrm{Be}$-derived erosion rates for tropical areas are incomplete representations of total mass loss from these landscapes because dissolved loads are incompletely accounted for by measurements of ${ }^{10} \mathrm{Be}$ in river sand. This discrepancy highlights the need for more studies that compare rock dissolution rates and cosmogenic nuclide-derived rates, in the tropics and beyond, to provide more accurate estimations of total landscape denudation.

\subsection{Comparison of long-term sediment generation rates with modern sediment yield records}

Sediment generation rates from central Cuba (determined cosmogenically) are lower on average than erosion rates calculated from island-wide sediment yield data (1-19 years of record, $n=32)$ collected during the peak of Soviet-assisted agricultural production (Pérez Zorrilla and Ya Karasik, 1989). This discrepancy suggests that modern sediment export rates in Cuba are 
https://doi.org/10.5194/gchron-2021-31

Preprint. Discussion started: 2 November 2021

(c) Author(s) 2021. CC BY 4.0 License.

(c) (i)

405 greater than long-term geologic rates of landscape change (Fig. 8). These two data sets are directly comparable because neither consider the solutional component of denudation. The increase in sediment yields over background sediment generation rates represents an increase in the physical component of denudation over time, likely due to human-landscape alteration through agriculture. However, the three watersheds with both sediment yield data and ${ }^{10} \mathrm{Be}$-inferred erosion rates suggest that this increase in erosion rates over background levels may not be uniform across the Cuban landscape. The

410 comparisons imply that sediment yield decreased by $33 \%$ in one basin, remained fairly uniform (decrease of $2 \%$ ) in another, and increased by $86 \%$ in the third.

These differences may be caused by variations in how well cosmogenic nuclide-derived rates capture the chemical component of denudation not reflected by the sediment yield data due to differences in chemical weathering depth between basins, or due to variability in the intensity of landscape alteration due to agriculture. However, the sediment yield data for

415 these three watersheds span fairly brief periods of record (9-15 years), leading to possible underestimates of modern average sediment delivery rates if episodic events that would increase sediment delivery have not been captured (Kirchner et al., 2001). This indicates the potential for modern erosion rates to be even higher than suggested by the sediment yield data. Longer-term sediment yield records are needed to more accurately assess how erosion rates in Cuba may have changed over time.

\section{Conclusions}

Our data, the first cosmogenic nuclide measurements from the island of Cuba, provide insight into how landscape denudation occurs in humid, tropical settings. Solution plays a large role in total mass flux, and significant mineral dissolution occurs along weathering fronts meters below the landscape surface. Rock type exerts the primary control on the pace of denudation, and precipitation influences total landscape denudation. We find evidence for thick mixed surface layers

425 in lowland basins and suggest that deep rock dissolution dominates denudational processes in basins where weathering products remain near the surface for long periods of time.

These findings highlight the necessity of accounting for mass loss by solution at depth when interpreting cosmogenic nuclide-derived rates in landscapes with the potential for significant rock dissolution. The discrepancy between high rock dissolution rates and low sediment generation rates observed in central Cuba emphasizes how relying on 430 cosmogenic nuclide measurements alone to determine total denudation rates can lead to considerable underestimations of total mass flux off landscapes. Summing rock dissolution rates and sediment generation rates can provide maximum 
https://doi.org/10.5194/gchron-2021-31

Preprint. Discussion started: 2 November 2021

(c) Author(s) 2021. CC BY 4.0 License.

(c) (i)
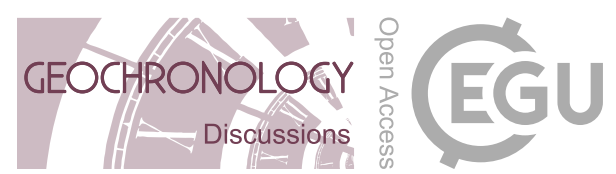

estimates of total denudation in landscapes with significant rock dissolution concentrated below the penetration depth of cosmic ray neutrons. These findings suggest that estimating rock dissolution rates is important when applying cosmogenic nuclides to other humid, tropical landscapes where solute fluxes carried in stream loads are significant.

\section{Data availability}

Data are under review at the Pangaea database (PDI-29915).

\section{Author contributions}

AHS, MKC, and PB contributed to project design. AGA, AGM, AHS, HCA, MKC, PBR, and RSH conducted fieldwork.

440 MKC prepared samples for laboratory analysis. GB, LS, MC, and MKC contributed to cosmogenic nuclide analysis. MKC led manuscript preparation; all authors assisted with data analysis and manuscript writing and review. GB, MKC, and AHS prepared the figures.

\section{Competing interests}

Some authors are members of the editorial board of Geochronology. The peer-review process was guided by an independent 445 editor, and the authors have also no other competing interests to declare.

\section{Acknowledgements}

Support for fieldwork and analyses provided by NSF EAR-1719249 and NSF EAR-1719240 to Bierman and Schmidt, NSF EAR 1735676 to Bierman, and Oberlin College funding to Schmidt. Researchers from Centro de Estudios Ambientales de Cienfuegos were supported by the MICATIN and ISOAGRI projects. We thank Jay Racela and Marika Massey-Bierman for

450 their assistance with laboratory work, and Marika Massey-Bierman, Monica Dix, and Victor Manuel Fonseca Pérez for assistance with fieldwork. 


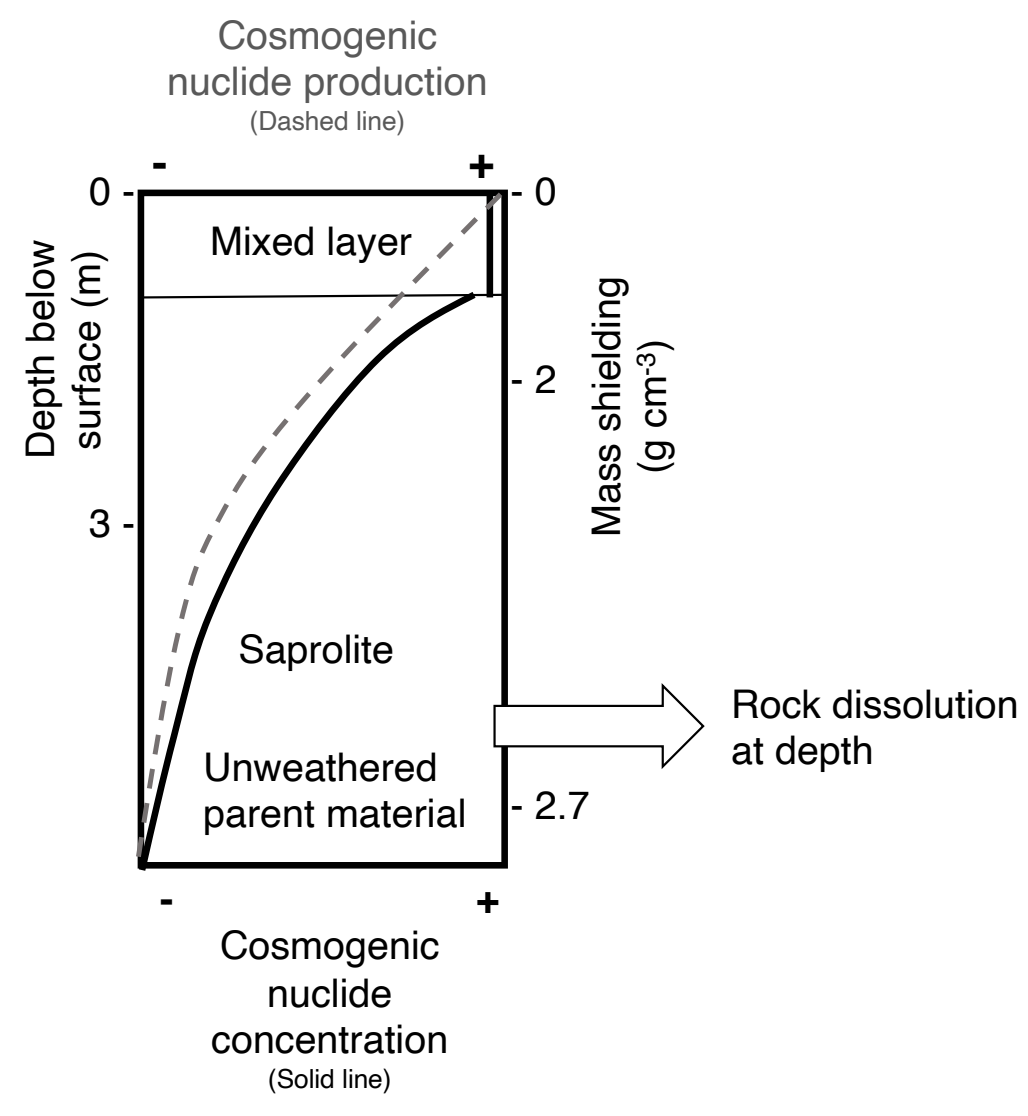

Figure 1: Conceptual diagram showing cosmogenic nuclide production and concentration in a column of soil, saprolite, and rock.

The dashed line shows decreasing production of cosmogenic nuclides with depth; solid line shows nuclide concentration with depth, and the white arrow represents mass loss by solution below the depth of significant cosmogenic nuclide production. 
https://doi.org/10.5194/gchron-2021-31

Preprint. Discussion started: 2 November 2021

(c) Author(s) 2021. CC BY 4.0 License.
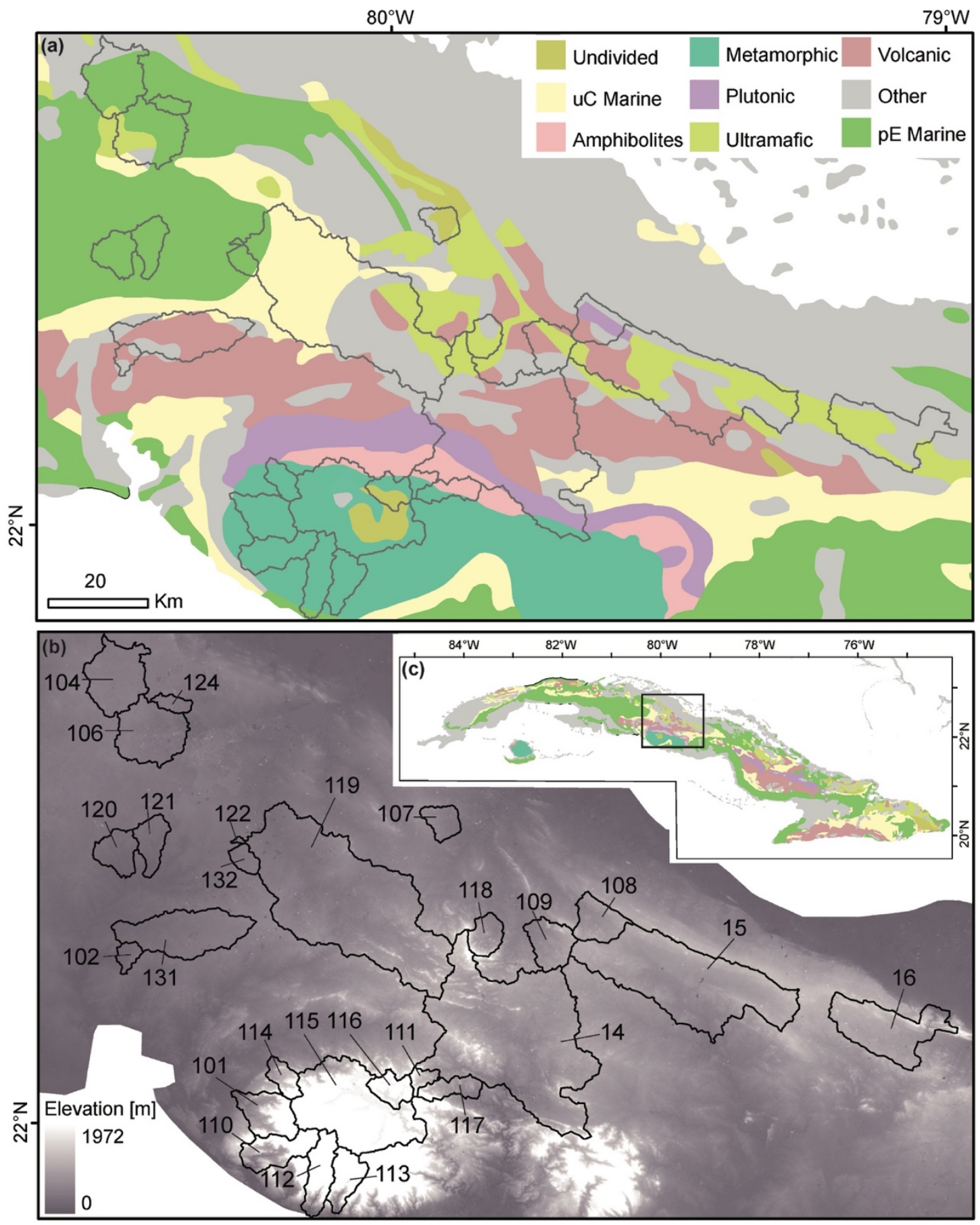

Figure 2: Maps showing underlying basin geology (panel A; French and Schenk, 2004), elevations (panel B; LPDAAC), and location of study sites within the island of Cuba (panel C). 
https://doi.org/10.5194/gchron-2021-31

Preprint. Discussion started: 2 November 2021

(c) Author(s) 2021. CC BY 4.0 License.
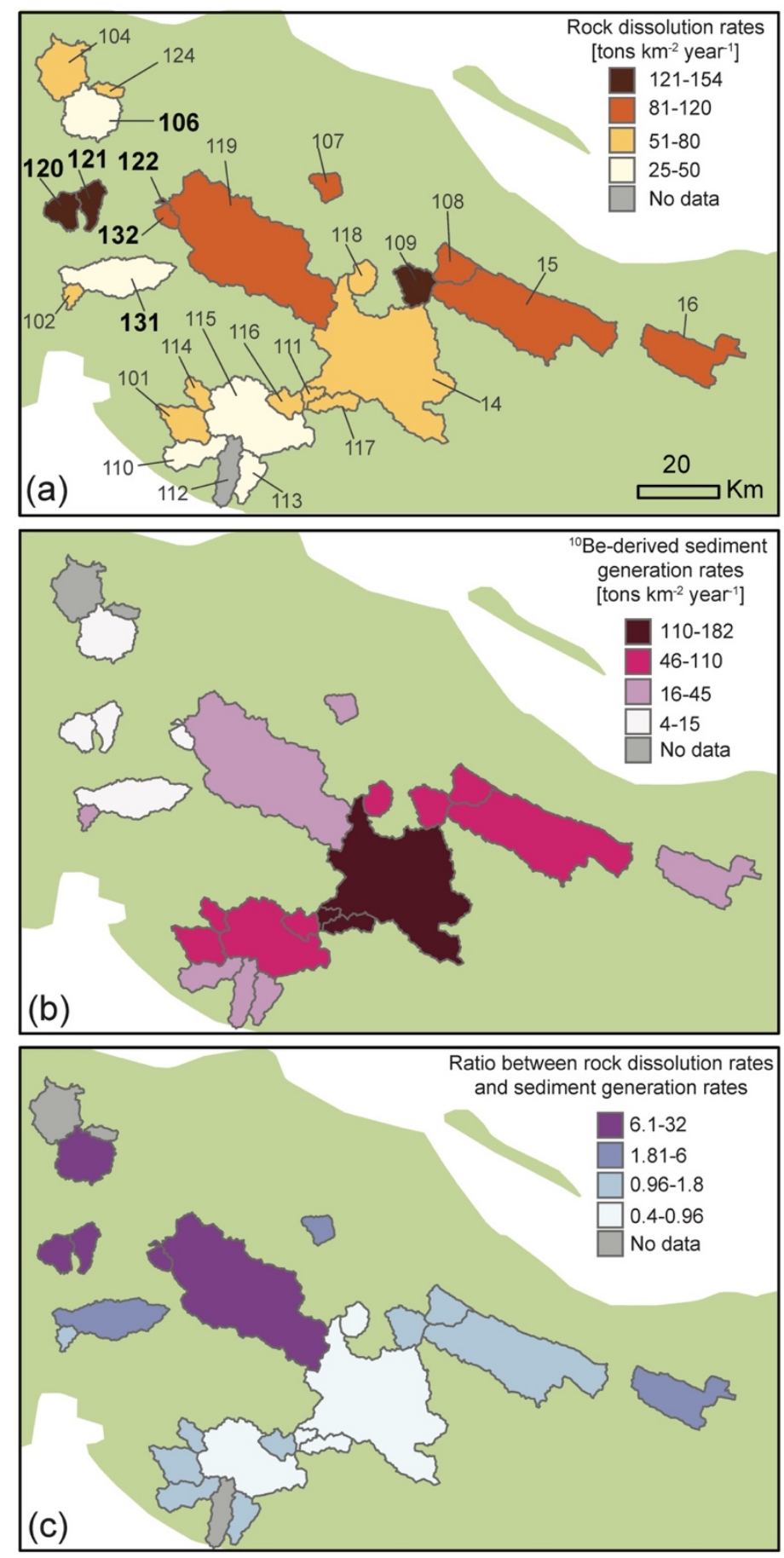

Figure 3: Maps showing rates of landscape change for each study watershed. Panel A shows measured sediment generation rates, and panel B shows measured rock dissolution. In both maps, darker colors in the basins indicate faster rates of landscape change. Panel $\mathrm{C}$ shows the ratio between rock dissolution rates and sediment generation rates; darker colors indicate larger ratios. 

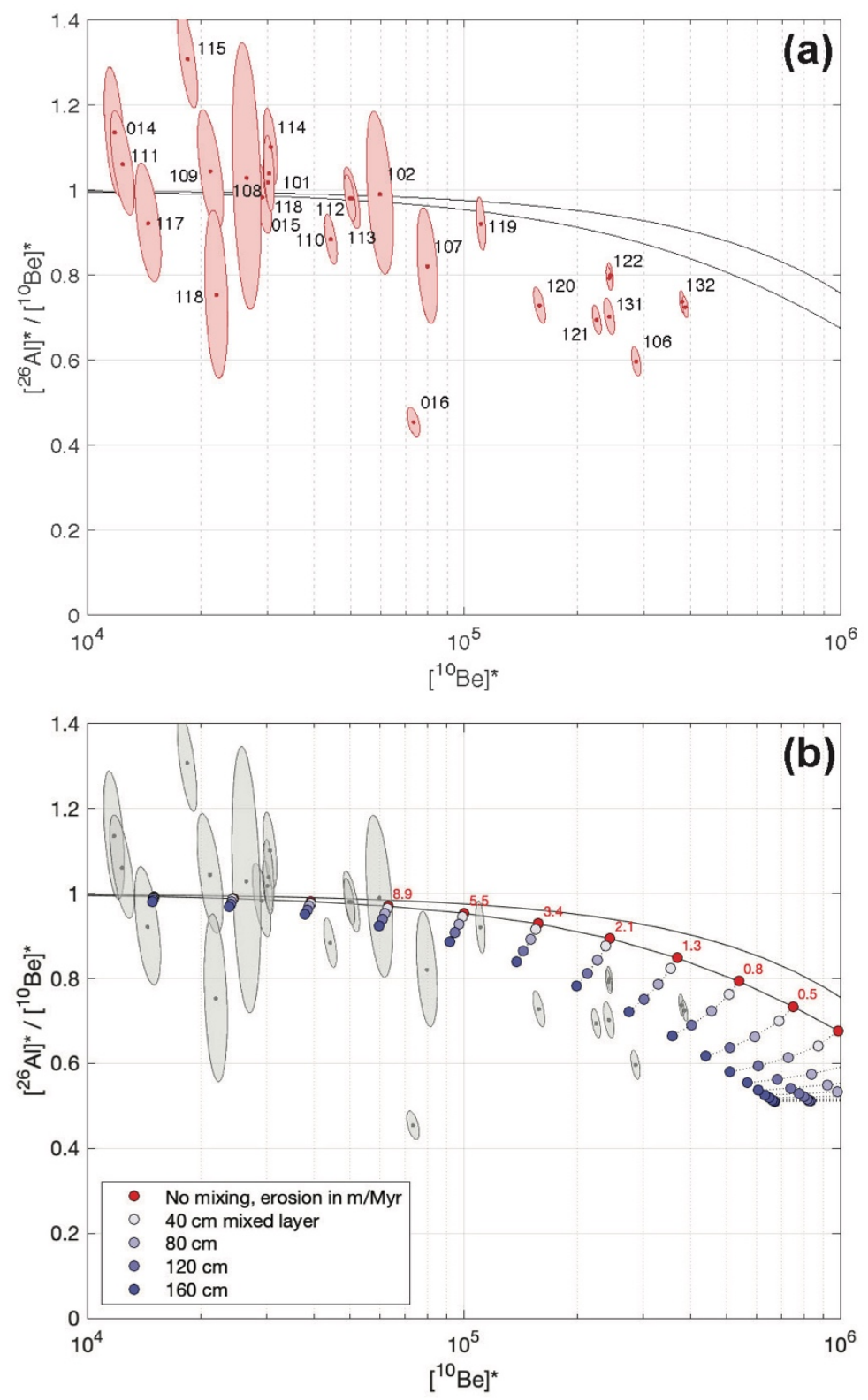

465 Figure 4: ${ }^{26} \mathrm{Al} /{ }^{10} \mathrm{Be}$ two-isotope plots. To permit comparison of data from different locations and elevations on the same plot, nuclide concentrations have been normalized by dividing measured concentrations by calculated mean production rates in the respective drainage basins, using production rate calculations from version 3 of the online exposure age calculator described by Balco et al. (2008) and subsequently updated. In both plots, uncertainty ellipses denote $68 \%$ confidence regions for the normalized nuclide concentrations, and the black lines are the boundaries of the simple exposure region (Lal, 1991) calculated using the conventional assumption of steady block erosion without vertical mixing. Panel A shows (leaving aside an anomalous result from $\mathrm{CU}-016)$ that ${ }^{26} \mathrm{Al} /{ }^{10} \mathrm{Be}$ ratios from basins with high nuclide concentrations, implying low erosion rates, are systematically lower than predicted by steady erosion without vertical mixing. Panel B shows that this inconsistency can, at least in part, be explained by the presence of a mixed layer. Circles show expected steady-state nuclide concentrations in a fully mixed surface layer calculated according to Lal and Chen (2005) for a range of erosion rates and mixed-layer thicknesses, which highlights that sediment derived from a deep mixed layer has lower nuclide concentrations and lower ${ }^{26} \mathrm{Al} /{ }^{10} \mathrm{Be}$ ratios than would be expected if the mixed layer were absent. Sample ID as in panel A. 
https://doi.org/10.5194/gchron-2021-31

Preprint. Discussion started: 2 November 2021

(c) Author(s) 2021. CC BY 4.0 License.

(c) (i)

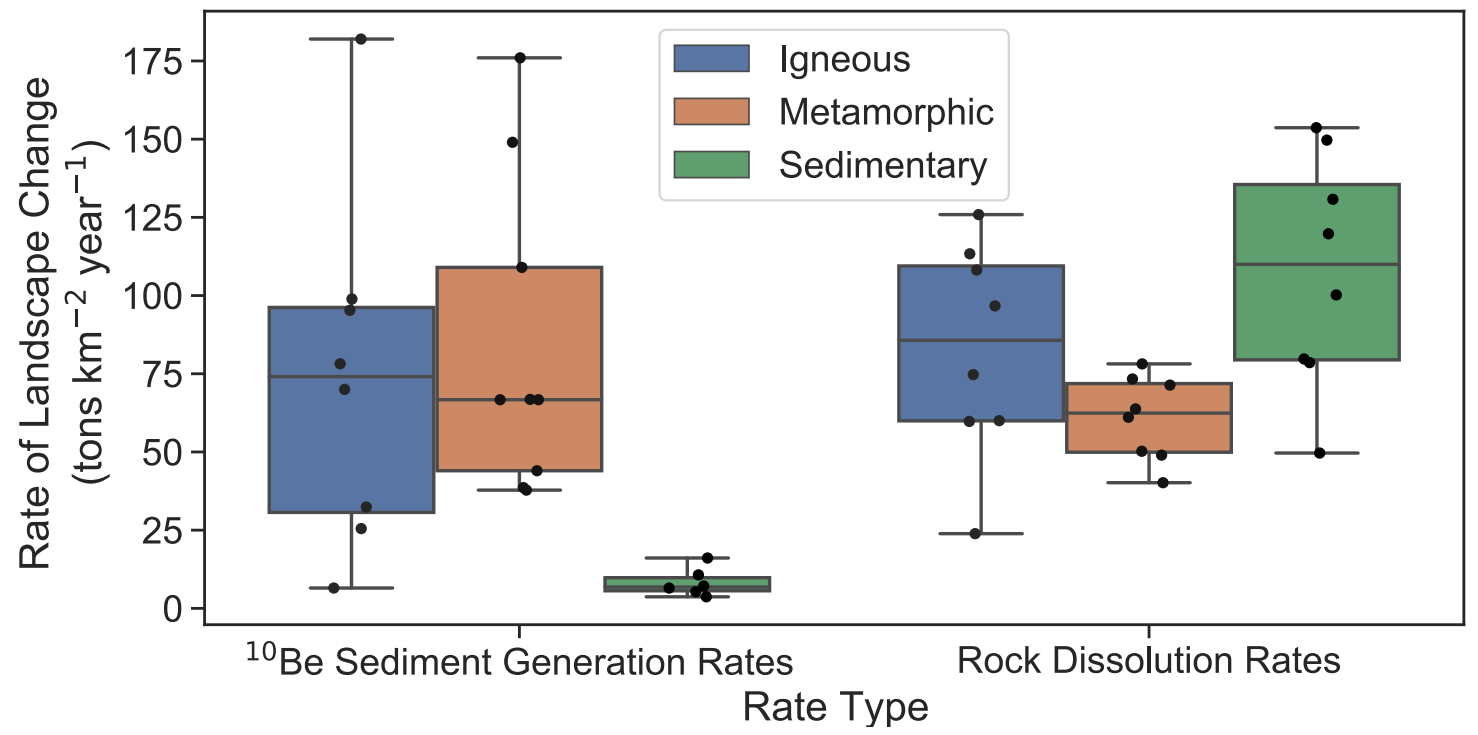

Figure 5: Sediment generation rates and rock dissolution rates, classified by rock type. Box plots show the maximum and minimum values in the lines extending from the box; the upper side of the box represents the upper quartile, the line inside of the box represents the median value, and the bottom of the box represents the lower quartile. 
https://doi.org/10.5194/gchron-2021-31

Preprint. Discussion started: 2 November 2021

(c) Author(s) 2021. CC BY 4.0 License.

(c) (i)

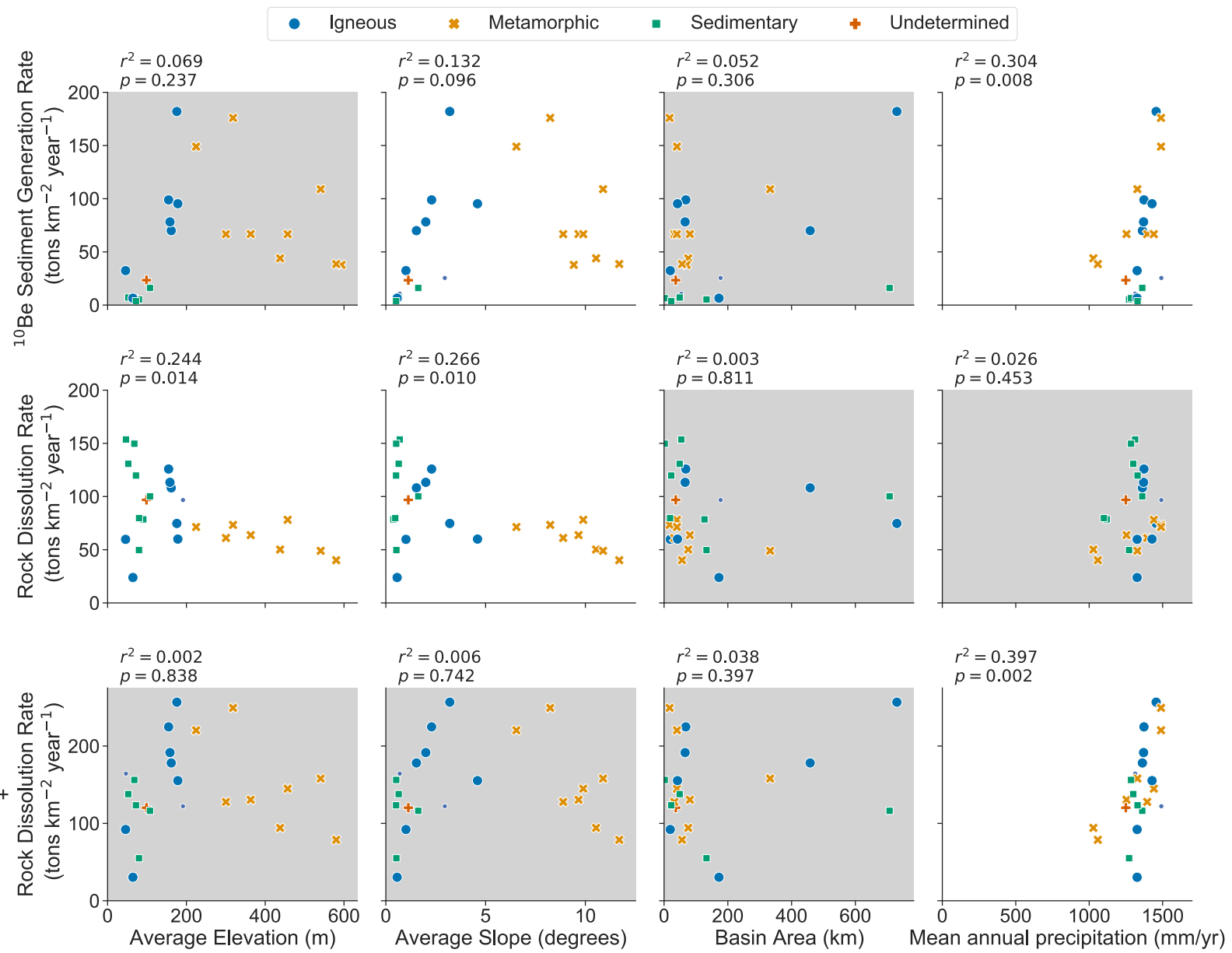

Figure 6: Relationship between measured ${ }^{10}$ Be-derived erosion rates, chemical denudation rates, and the sum of chemical denudation rates and ${ }^{10} \mathrm{Be}$-derived erosion rates to basin characteristics. Different shaped/colored points represent the dominant underlying rock type in that basin. Plots with $p>0.1$ are shown with a gray background. 
https://doi.org/10.5194/gchron-2021-31

Preprint. Discussion started: 2 November 2021

(c) Author(s) 2021. CC BY 4.0 License.

(c) (i)
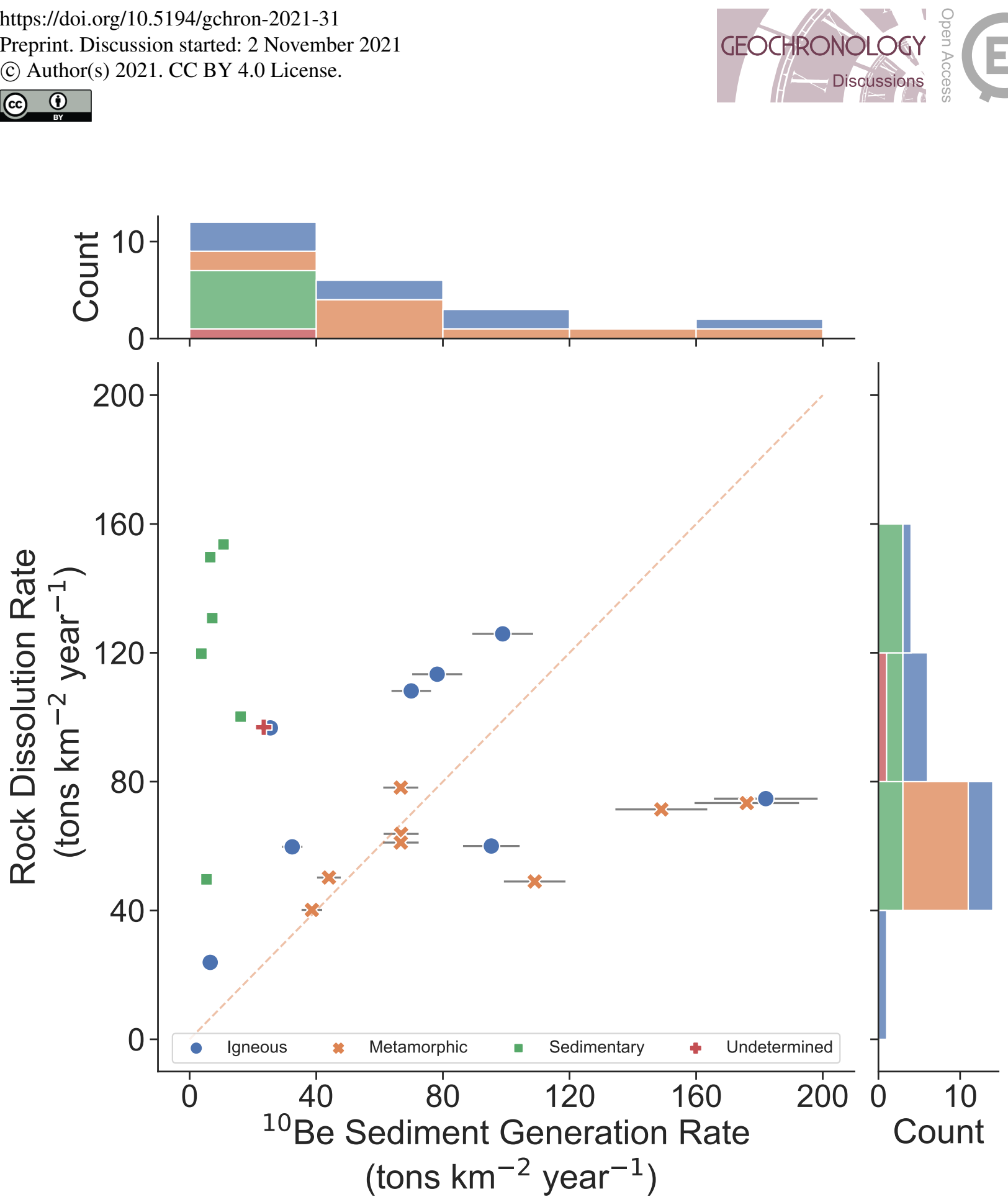

Figure 7: Scatterplot of rock dissolution rates vs. sediment generation rates. Dashed orange line is a 1:1 line. Horizontal lines extending from the points demonstrate the uncertainty associated with the calculation of sediment generation rates. Histograms on axes show distribution of data. 
https://doi.org/10.5194/gchron-2021-31

Preprint. Discussion started: 2 November 2021

(c) Author(s) 2021. CC BY 4.0 License.

(c) (i)

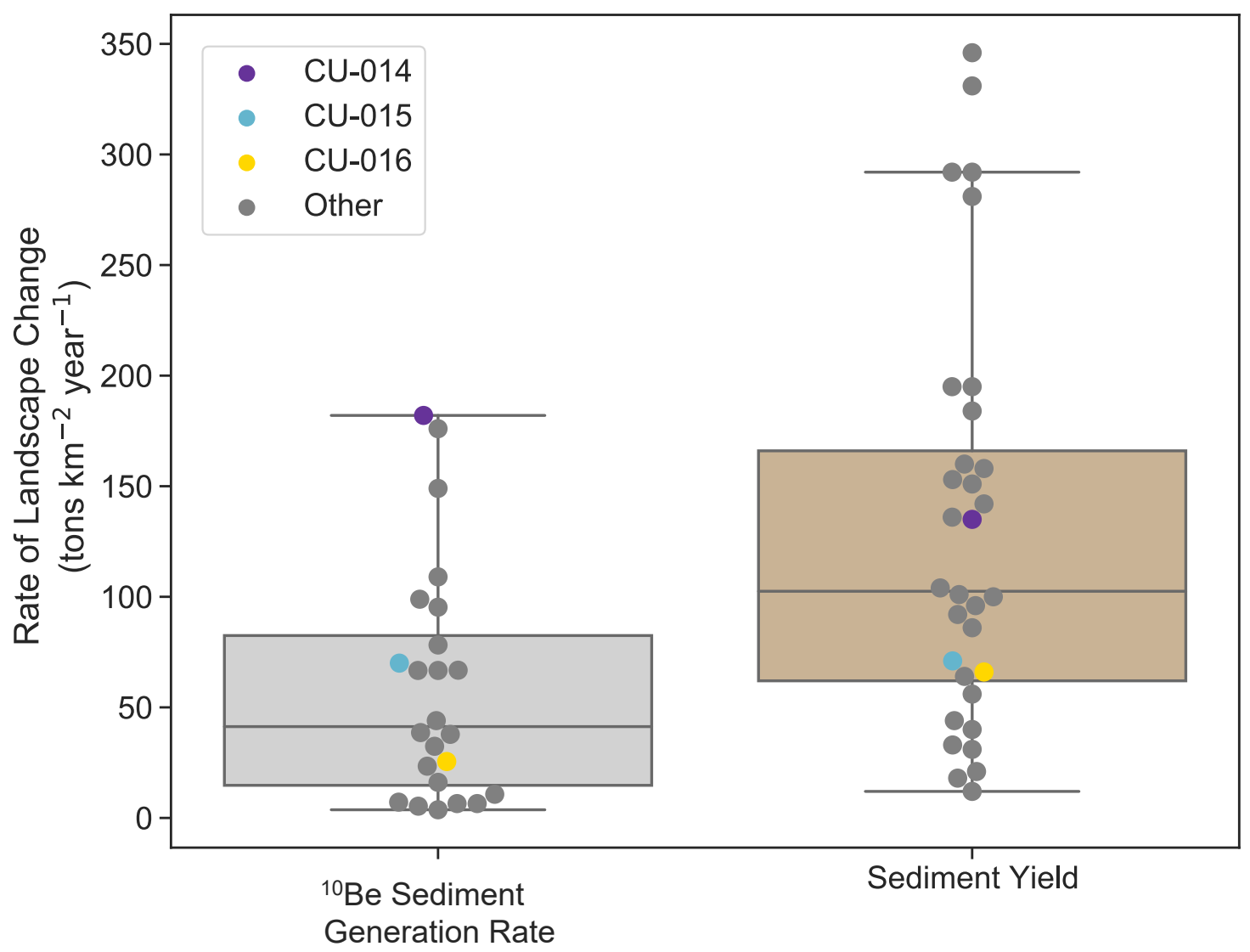

490 Figure 8: Boxplots comparing long-term sediment generation rates measured in this study $(\mathbf{n}=\mathbf{2 4})$ and erosion rates calculated using modern sediment yield data from island-wide observations $(n=32)$. Box plots show the maximum and minimum values in the lines extending from the box; the upper side of the box represents the upper quartile, the line inside of the box represents the median value, and the bottom of the box represents the lower quartile. Basins with both measurements are shown as colored points. Sediment yield data are from Pérez Zorrilla and Ya Karasik (1989) and represent points across the island of Cuba.

\section{References}

Reference List

Anderson, S. P., Blanckenburg, F. v., and White, A. F.: Physical and Chemical Controls on the Critical Zone, Elements, 3, 315-319, 2007.

500 Balco, G. and Shuster, D. L.: Production rate of cosmogenic $21 \mathrm{Ne}$ in quartz estimated from $10 \mathrm{Be}, 26 \mathrm{Al}$, and $21 \mathrm{Ne}$ concentrations in slowly eroding Antarctic bedrock surfaces, Earth and Planetary Science Letters, 281, 48-58, 10.1016/j.epsl.2009.02.006, 2009. 
https://doi.org/10.5194/gchron-2021-31

Preprint. Discussion started: 2 November 2021

(c) Author(s) 2021. CC BY 4.0 License.

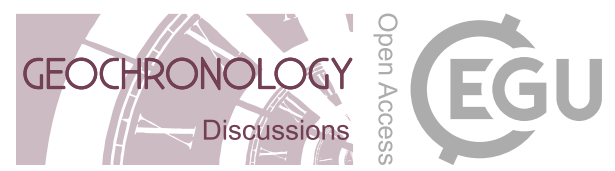

Balco, G., Stone, J. O., Lifton, N. A., and Dunai, T. J.: A complete and easily accessible means of calculating surface exposure ages or erosion rates from 10Be and 26Al measurements, Quaternary Geochronology, 3, 174-195, 10.1016/j.quageo.2007.12.001, 2008.

Balter-Kennedy, A., Bromley, G., Balco, G., Thomas, H., and Jackson, M. S.: A 14.5-million-year record of East Antarctic Ice Sheet

505 fluctuations from the central Transantarctic Mountains, constrained with cosmogenic $<$ sup $>3</$ sup $>$ He, $<$ sup $>10</$ sup $>$ Be, $<$ sup $>21</$ sup $>\mathrm{Ne}$, and $<\sup >26</$ sup $>$ Al, The Cryosphere, 14, 2647-2672, 10.5194/tc-14-2647-2020, 2020.

Barreto, H. N., Varajão, C. A. C., Braucher, R., Bourlès, D. L., Salgado, A. A. R., and Varajão, A. F. D. C.: Denudation rates of the Southern Espinhaço Range, Minas Gerais, Brazil, determined by in situ-produced cosmogenic beryllium-10, Geomorphology, 191, 1-13, 10.1016/j.geomorph.2013.01.021, 2013.

510 Beck, H. E., de Roo, A., and van Dijk, A. I. J. M.: Global Maps of Streamflow Characteristics Based on Observations from Several Thousand Catchments*, Journal of Hydrometeorology, 16, 1478-1501, 10.1175/jhm-d-14-0155.1, 2015.

Beck, H. E., Vergopolan, N., Pan, M., Levizzani, V., van Dijk, A. I. J. M., Weedon, G. P., Brocca, L., Pappenberger, F., Huffman, G. J., and Wood, E. F.: Global-scale evaluation of 22 precipitation datasets using gauge observations and hydrological modeling, Hydrology and Earth System Sciences, 21, 6201-6217, 10.5194/hess-21-6201-2017, 2017.

515 Bennett, H. H. and Allison, R. V.: The soils of Cuba, Tropical Plant Research Foundation, Washington, D.C.1928.

Betancourt, C., Suárez, R., and Jorge, F.: Influencia de los procesos naturales y antrópicos sobre la calidad del agua en cuatro embalses cubanos, Limnetica, 31, 193-204, 2012.

Bierman, P. and Steig, E.: Estimating rates of denudation using cosmogenic isotope abundances in sediment, Earth Surface Processes and Landforms, 21, 103-203, 1996.

520 Bierman, P., Herdandez, R. S., Schmidt, A., Aguila, H. C., Alvazrez, Y., Arruebarrena, A., Campbell, M. K., Dethier, D., Dix, M., Massey-Bierman, M., Moya, A. G., Perdrial, J., Racela, J., and Alonso-Hernandez, C.: ¡Cuba! River Water Chemistry Reveals Rapid Chemical Weathering, the Echo of Uplift, and the Promise of More Sustainable Agriculture, GSA Today, 30, 4-10, 2020.

Bierman, P. R., Marsella, K. A., Patterson, C., Davis, P. T., \& Caffee, M.: Mid-Pleistocene cosmogenic minimum-age limits for preWisconsinan glacial surfaces in southwestern Minnesota and southern Baffin Island: a multiple nuclide approach, Geomorphology, 27, 27-

$52539,1999$.

Brown, E. T., Stallard, R. F., Larsen, M. C., Raisbeck, G. M., and Yiou, F.: Denudation rates determined from the accumulation of in situproduced 10Be in the Luquillo Experimental Forest, Puerto Rico, Earth and Planetary Science Letters, 129, 193-202, 1995.

Chapela Lara, M., Buss, H. L., Pogge von Strandmann, P. A. E., Schuessler, J. A., and Moore, O. W.: The influence of critical zone processes on the $\mathrm{Mg}$ isotope budget in a tropical, highly weathered andesitic catchment, Geochimica et Cosmochimica Acta, 202, 77-100,

530 10.1016/j.gca.2016.12.032, 2017.

Cherem, L. F. S., Varajão, C. A. C., Braucher, R., Bourlés, D., Salgado, A. A. R., and Varajão, A. C.: Long-term evolution of denudational escarpments in southeastern Brazil, Geomorphology, 173-174, 118-127, 10.1016/j.geomorph.2012.06.002, 2012.

Codilean, A. T., Munack, H., Cohen, T. J., Saktura, W. M., Gray, A., and Mudd, S. M.: OCTOPUS: An Open Cosmogenic Isotope and Luminescence

535 Database, Earth System Science Data, 10.5194/essd-2018-32, 2018.

Corbett, L. B., Bierman, P. R., and Rood, D. H.: An approach for optimizing in situ cosmogenic 10 Be sample preparation, Quaternary Geochronology, 33, 24-34, 10.1016/j.quageo.2016.02.001, 2016.

Corbett, L. B., Bierman, P. R., Woodruff, T. E., and Caffee, M. W.: A homogeneous liquid reference material for monitoring the quality and reproducibility of in situ cosmogenic 10Be and 26Al analyses, Nuclear Instruments and Methods in Physics Research Section B:

540 Beam Interactions with Materials and Atoms, 456, 180-185, 10.1016/j.nimb.2019.05.051, 2019.

Derrieux, F., Siame, L. L., Bourlès, D. L., Chen, R.-F., Braucher, R., Léanni, L., Lee, J.-C., Chu, H.-T., and Byrne, T. B.: How fast is the denudation of the Taiwan mountain belt? Perspectives from in situ cosmogenic 10Be, Journal of Asian Earth Sciences, 88, 230-245, 10.1016/j.jseaes.2014.03.012, 2014.

Dixon, J. L., Heimsath, A. M., and Amundson, R.: The critical role of climate and saprolite weathering in landscape evolution, Earth

545 Surface Processes and Landforms, 34, 1507-1521, 10.1002/esp.1836, 2009a.

Dixon, J. L., Heimsath, A. M., Kaste, J., and Amundson, R.: Climate-driven processes of hillslope weathering, Geology, 37, 975-978, 10.1130/g30045a.1, 2009b.

Dunne, T.: Rates of chemical denudation of silicate rocks in tropical catchments, Nature, 274, 244-246, 1978.

Ferrier, K. L. and Kirchner, J. W.: Effects of physical erosion on chemical denudation rates: A numerical modeling study of soil-mantled

550 hillslopes, Earth and Planetary Science Letters, 272, 591-599, 10.1016/j.epsl.2008.05.024, 2008.

French, C. D. and Schenk, C. J.: Map showing geology, oil and gas fields, and geologic provinces of the Caribbean Region: U.S. Geological Survey Open-File Report 97-470-K, 2004.

Galford, G. L., Fernandez, M., Roman, J., Monasterolo, I., Ahamed, S., Fiske, G., González, P., and Kaufman, L.: Cuban land use and conservation, from rainforests to coral reefs, Bulletin of Marine Science, 10.5343/bms.2017.1026, 2018.

555 Granger, D. E.: A review of burial dating methods using 26Al and 10Be, in: In-Situ Produced Cosmogenic Nuclides and Quantification of Geological Processes, edited by: Siame, L. L., Bourlès, D. L., and Brown, E. T., The Geological Society of America, 1-16, 2006. 
https://doi.org/10.5194/gchron-2021-31

Preprint. Discussion started: 2 November 2021

(c) Author(s) 2021. CC BY 4.0 License.

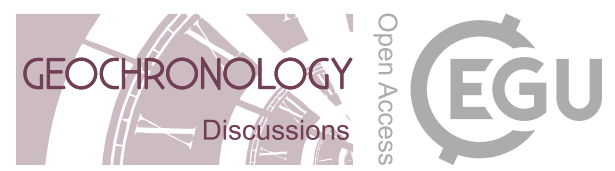

Granger, D. E. and Muzikar, P.: Dating sediment burial with in situ-produced cosmogenic nuclides: theory, techniques, and limitations, Earth and Planetary Science Letters, 188, 269-281, 2001.

Granger, D. E., Kirchner, J. W., and Finkel, R.: Spatially Averaged Long-Term Erosion Rates Measured from In Situ-Produced

560 Cosmogenic Nuclides in Alluvial Sediment, The Journal of Geology, 104, 249-257, 1996.

Hijmans, R. J., Cameron, S. E., Parra, J. L., Jones, P. G., and Jarvis, A.: Very high resolution interpolated climate surfaces for global land areas, International Journal of Climatology, 25, 1965-1978, 10.1002/joc.1276, 2005.

Hinderer, M., Pflanz, D., and Schneider, S.: Chemical Denudation Rates in the Humid Tropics of East Africa and Comparison with 10BeDerived Erosion Rates, Procedia Earth and Planetary Science, 7, 360-364, 10.1016/j.proeps.2013.03.047, 2013.

565 Hu, X., Kirby, E., Pan, B., Granger, D. E., and Su, H.: Cosmogenic burial ages reveal sediment reservoir dynamics along the Yellow River, China, Geology, 39, 839-842, 10.1130/g32030.1, 2011.

Iturralde-Vinent, M. A., García-Casco, A., Rojas-Agramonte, Y., Proenza, J. A., Murphy, J. B., and Stern, R. J.: The geology of Cuba: A brief overview and synthesis, GSA Today, 4-10, 10.1130/gsatg296a.1, 2016.

Jonell, T. N., Clift, P. D., Hoang, L. V., Hoang, T., Carter, A., Wittmann, H., Böning, P., Pahnke, K., and Rittenour, T.: Controls on

570 erosion patterns and sediment transport in a monsoonal, tectonically quiescent drainage, Song Gianh, central Vietnam, Basin Research, 29, 659-683, 10.1111/bre.12199, 2017.

Kirchner, J. W., Finkel, R. C., Riebe, C. S., Granger, D. E., Clayton, J. L., King, J. G., and Megahan, W. F.: Mountain erosion over 10 yr, 10 k.y., and 10 m.y. time scales, Geology, 29, 591-594, 2001.

Klein, J., Giegengack, R., Middleton, R., Sharma, P., Underwood, J., and Weeks, R.: Revealing histories of exposure using in situ

575 produced 26Al and 10Be in Libyan Desert glass, Radiocarbon, 28, 547-555, 1986.

Kohl, C. P. and Nishiizumi, K.: Chemical isolation of quartz for measurement of in-situ -produced cosmogenic nuclides, Geochimica et Cosmochimica Acta, 56, 3583-3587, 1992.

Kurtz, A. C., Lugolobi, F., and Salvucci, G.: Germanium-silicon as a flow path tracer: Application to the Rio Icacos watershed, Water Resources Research, 47, 10.1029/2010wr009853, 2011.

580 Lal, D.: Cosmic ray labeling of erosion surfaces: in situ nuclide production rates and erosion models, Earth and Planetary Science Letters, 104, 424-439, 1991.

Lal, D. and Chen, J.: Cosmic ray labeling of erosion surfaces II: Special cases of exposure histories of boulders, soils and beach terraces, Earth and Planetary Science Letters, 236, 797-813, 10.1016/j.epsl.2005.05.025, 2005.

Larsen, I. J., Montgomery, D. R., and Greenberg, H. M.: The contribution of mountains to global denudation, Geology, 42, 527-530,

$58510.1130 / \mathrm{g} 35136.1,2014$.

Llacer, I. D.: Comportamiento de la precipitación en estaciones meteorológicas seleccionadas de Cuba, Facultad de Geografía, La Universidad de la Habana, La Habana, Cuba, 2012.

LPDAAC: ASTER GDEM (Volume 2019) [dataset],

Lukens, C. E., Riebe, C. S., Sklar, L. S., and Shuster, D. L.: Grain size bias in cosmogenic nuclide studies of stream sediment in steep

590 terrain, Journal of Geophysical Research: Earth Surface, 121, 978-999, 10.1002/2016jf003859, 2016.

Makhubela, T. V., Kramers, J. D., Scherler, D., Wittmann, H., Dirks, P. H. G. M., and Winkler, S. R.: Effects of long soil surface residence times on apparent cosmogenic nuclide denudation rates and burial ages in the Cradle of Humankind, South Africa, Earth Surface Processes and Landforms, 44, 2968-2981, 10.1002/esp.4723, 2019.

Mandal, S. K., Lupker, M., Burg, J.-P., Valla, P. G., Haghipour, N., and Christl, M.: Spatial variability of 10 Be-derived erosion rates

595 across the southern Peninsular Indian escarpment: A key to landscape evolution across passive margins, Earth and Planetary Science Letters, 425, 154-167, 10.1016/j.epsl.2015.05.050, 2015.

Marshall, J. A., Roering, J. J., Gavin, D. G., and Granger, D. E.: Late Quaternary climatic controls on erosion rates and geomorphic processes in western Oregon, USA, Geological Society of America Bulletin, 129, 715-731, 10.1130/b31509.1, 2017.

Modenesi-Gauttieri, M. C., de Toledo, M. C. M., Hiruma, S. T., Taioli, F., and Shimada, H.: Deep weathering and landscape evolution in a

600 tropical plateau, Catena, 85, 221-230, 10.1016/j.catena.2011.01.006, 2011.

Moore, O. W., Buss, H. L., and Dosseto, A.: Incipient chemical weathering at bedrock fracture interfaces in a tropical critical zone system, Puerto Rico, Geochimica et Cosmochimica Acta, 252, 61-87, 10.1016/j.gca.2019.02.028, 2019.

Nearing, M. A., Xie, Y., Liu, B., and Ye, Y.: Natural and anthropogenic rates of soil erosion, International Soil and Water Conservation Research, 5, 77-84, 10.1016/j.iswcr.2017.04.001, 2017.

605 Nishiizumi, K.: Preparation of 26Al AMS standards, Nuclear Instruments and Methods in Physics Research Section B: Beam Interactions with Materials and Atoms, 223-224, 388-392, https://doi.org/10.1016/j.nimb.2004.04.075, 2004.

Nishiizumi, K., Imamura, M., Caffee, M. W., Southon, J. R., Finkel, R. C., and McAninch, J.: Absolute calibration of 10Be AMS standards, Nuclear Instruments and Methods in Physics Research Section B: Beam Interactions with Materials and Atoms, 258, 403-413, 10.1016/j.nimb.2007.01.297, 2007.

610 Nishiizumi, K., Winterer, E. L., Kohl, C. P., Klein, J., Middleton, R., Lal, D., and Arnold, J. R.: Cosmic ray production rates of10Be and26Al in quartz from glacially polished rocks, Journal of Geophysical Research, 94, 10.1029/JB094iB12p17907, 1989.

Ollier, C. D.: Deep Weathering, Groundwater and Climate, Geografiska Annaler, 70, 285- 290, 1988. 
https://doi.org/10.5194/gchron-2021-31

Preprint. Discussion started: 2 November 2021

(c) Author(s) 2021. CC BY 4.0 License.

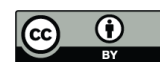

Pardo, G.: Geology of Cuba, AAPG Studies in Geology, The American Association of Petroleum Geologists, Tulsa, Oklahoma2009.

Pérez Zorrilla, W. and Ya Karasik, G.: El escurrimiento solido y la erosion hidrica actual de Cuba, Ciencias de la tierra y del espacio, 15-

$61516,67-76,1989$

Pope, G. A.: Weathering in the tropics, and related extratropical processes, in: Treatise on Geomorphology, edited by: Shroder, J., Weathering and Soils Geomorphology, Academic Press, 2013.

Portenga, E. W. and Bierman, P. R.: Understanding Earth's eroding surface with 10Be, GSA Today, 21, 4-10, 10.1130/g111a.1, 2011.

Préndez, M., López, R., and Carrillo, E.: Physical and Chemical Components of Cuba's Rain: Effects on Air Quality, International Journal

620 of Atmospheric Sciences, 2014, 1-8, 10.1155/2014/680735, 2014.

Pulina, M. and Fagundo, J. R.: Tropical karst and chemical denudation of western Cuba, Geographia Polonica, 60, 195-216, 1992.

Rad, S., Allegre, C., and Louvat, P.: Hidden erosion on volcanic islands, Earth and Planetary Science Letters, 262, 109-124, 10.1016/j.epsl.2007.07.019, 2007.

Rad, S., Rivé, K., Vittecoq, B., Cerdan, O., and Allègre, C. J.: Chemical weathering and erosion rates in the Lesser Antilles: An overview

in Guadeloupe, Martinique and Dominica, Journal of South American Earth Sciences, 45, 331-344, 10.1016/j.jsames.2013.03.004, 2013.

Regard, V., Carretier, S., Boeglin, J.-L., Ndam Ngoupayou, J.-R., Dzana, J.-G., Bedimo Bedimo, J.-P., Riotte, J., and Braun, J.-J.: Denudation rates on cratonic landscapes: comparison between suspended and dissolved fluxes, and10Be analysis in the Nyong and Sanaga River basins, south Cameroon, Earth Surface Processes and Landforms, 41, 1671-1683, 10.1002/esp.3939, 2016.

Reinhardt, L. J., Bishop, P., Hoey, T. B., Dempster, T. J., and Sanderson, D. C. W.: Quantification of the transient response to base-level

630 fall in a small mountain catchment: Sierra Nevada, southern Spain, Journal of Geophysical Research, 112, 10.1029/2006jf000524, 2007.

Reusser, L., Bierman, P., and Rood, D.: Quantifying human impacts on rates of erosion and sediment transport at a landscape scale, Geology, 43, 171-174, 2015.

Riebe, C. S. and Granger, D. E.: Quantifying effects of deep and near-surface chemical erosion on cosmogenic nuclides in soils, saprolite, and sediment, Earth Surface Processes and Landforms, 38, 523-533, 10.1002/esp.3339, 2013.

635 Riebe, C. S., Kirchner, J. W., and Finkel, R. C.: Long-term rates of chemical weathering and physical erosion from cosmogenic nuclides and geochemical mass balance, Geochimica et Cosmochimica Acta, 67, 4411-4427, 10.1016/s0016-7037(03)00382-x, 2003.

Riebe, C. S., Kirchner, J. W., and Granger, D. E.: Quantifying quartz enrichment and its consequences for cosmogenic measurements of erosion rates from alluvial sediment and regolith, Geomorphology, 15-19, $2001 \mathrm{a}$.

Riebe, C. S., Kirchner, J. W., Granger, D. E., and Finkel, R. C.: Minimal climatic control on erosion rates in the Sierra Nevada, California,

640 The Journal of Geology, 29, 447-450, 2001 b.

Salgado, A. A. R., Braucher, R., Colin, F., Nalini, H. A., Varajão, A. F. D. C., and Varajão, C. A. C.: Denudation rates of the Quadrilátero Ferrífero (Minas Gerais, Brazil): Preliminary results from measurements of solute fluxes in rivers and in situ-produced cosmogenic 10Be, Journal of Geochemical Exploration, 88, 313-317, 10.1016/j.gexplo.2005.08.064, 2006.

Scherler, D., Bookhagen, B., and Strecker, M. R.: Tectonic control on10Be-derived erosion rates in the Garhwal Himalaya, India, Journal

645 of Geophysical Research: Earth Surface, 119, 83-105, 10.1002/2013jf002955, 2014.

Schopka, H. H. and Derry, L. A.: Chemical weathering fluxes from volcanic islands and the importance of groundwater: The Hawaiian example, Earth and Planetary Science Letters, 339-340, 67-78, 10.1016/j.eps1.2012.05.028, 2012.

Small, E. E., Anderson, R. S., and Hancock, G. S.: Estimates of the rate of regolith production using $10 \mathrm{Be}$ and $26 \mathrm{Al}$ from an alpine hillslope, Geomorphology, 131-150, 1999.

650 Sosa Gonzalez, V., Bierman, P. R., Fernandes, N. F., and Rood, D. H.: Long-term background denudation rates of southern and southeastern Brazilian watersheds estimated with cosmogenic 10Be, Geomorphology, 268, 54-63, 10.1016/j.geomorph.2016.05.024, 2016 .

Sosa Gonzalez, V., Bierman, P. R., Nichols, K. K., and Rood, D. H.: Long-term erosion rates of Panamanian drainage basins determined using in situ $10 \mathrm{Be}$, Geomorphology, 275, 1-15, 10.1016/j.geomorph.2016.04.025, 2016b.

655 Stone, J. O.: Air pressure and cosmogenic isotope production, Journal of Geophysical Research: Solid Earth, 105, 23753-23759, 10.1029/2000jb900181, 2000.

Struck, M., Jansen, J. D., Fujioka, T., Codilean, A. T., Fink, D., Egholm, D. L., Fülöp, R.-H., Wilcken, K. M., and Kotevski, S.: Soil production and transport on postorogenic desert hillslopes quantified with 10Be and 26Al, GSA Bulletin, 130, 1017-1040, 10.1130/b31767.1, 2018 .

660 Vasconcelos, P. M., Farley, K. A., Stone, J., Piacentini, T., and Fifield, L. K.: Stranded landscapes in the humid tropics: Earth's oldest land surfaces, Earth and Planetary Science Letters, 519, 152-164, 10.1016/j.eps1.2019.04.014, 2019.

von Blackenburg, F., Hewawasam, T., and Kubik, P. W.: Cosmogenic nuclide evidence for low weathering and denudation in the wet, tropical highlands of Sri Lanka, Journal of Geophysical Research, 109, 1-22, 10.1029/2003JF000049, 2004.

West, A., Galy, A., and Bickle, M.: Tectonic and climatic controls on silicate weathering, Earth and Planetary Science Letters, 235, 211-

665 228, 10.1016/j.epsl.2005.03.020, 2005.

Whitbeck, R. H.: Geographical Relations in the Development of Cuban Agriculture, American Geographical Society, 12, $223-240,1922$. 
https://doi.org/10.5194/gchron-2021-31

Preprint. Discussion started: 2 November 2021

(c) Author(s) 2021. CC BY 4.0 License.

(c) (i)
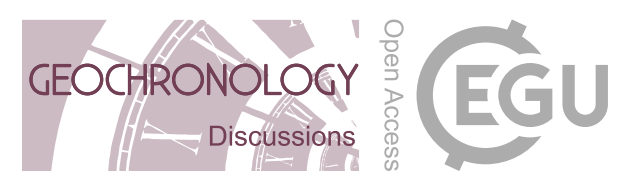

White, A., Blum, A., Schulz, M., Vivit, D., Stonestrom, D., Larsen, M., Murphy, S., and Eberl, D.: Chemical weathering in a tropical watershed, Luquillo Mountains, Puerto Rico: I. Long-term versus short-term weathering fluxes, Geochemica et Cosmochimica Acta, 62, 209-226, 1998.

670 White, A. F. and Blum, A. E.: Effects of climate on chemical weathering in waterhseds, Geochemica et Cosmochimica Acta, 59, 1729$1747,1995$.

Wittmann, H., von Blanckenburg, F., Maurice, L., Guyot, J. L., and Kubik, P. W.: Recycling of Amazon floodplain sediment quantified by cosmogenic 26Al and 10Be, Geology, 39, 467-470, 10.1130/g31829.1, 2011. 